\title{
Reduction of Ether-Type Glycerophospholipids, Plasmalogens, by NF- $\kappa$ B Signal Leading to Microglial Activation
}

\author{
Md. Shamim Hossain, ${ }^{1}$ Yuichi Abe, ${ }^{3}$ Fatma Ali, ${ }^{2}{ }^{\circledR}$ Mohammed Youssef, ${ }^{2}$ Masanori Honsho, ${ }^{3}$ Yukio Fujiki, ${ }^{3}$ \\ and Toshihiko Katafuchi ${ }^{1}$ \\ ${ }^{1}$ Department of Neuroinflammation and Brain Fatigue Science, ${ }^{2}$ Department of Integrative Physiology, Graduate School of Medical Sciences, and ${ }^{3}$ Medical \\ Institute of Bioregulation, Kyushu University, Fukuoka 812-8582, Japan
}

Neuroinflammation characterized by activation of glial cells is observed in various neurodegenerative diseases including Alzheimer's disease (AD). Although the reduction of ether-type glycerophospholipids, plasmalogens (Pls), in the brain is reported in AD patients, the mechanism of the reduction and its impact on neuroinflammation remained elusive. In the present study, we found for the first time that various inflammatory stimuli reduced Pls levels in murine glial cells via NF- $\kappa$ B activation, which then downregulated a Pls-synthesizing enzyme, glycerone phosphate 0 -acyltransferase (Gnpat) through increased c-Myc recruitment onto the Gnpat promoter. We also found that systemic injection of lipopolysaccharide, aging, and chronic restraint stress reduced brain Pls contents that were associated with glial NF- $\kappa$ B activation, an increase in c-Myc expression, and downregulation of Gnpat in the mouse cortex and hippocampus. More interestingly, the reduction of Pls contents in the murine cortex itself could increase the activated phenotype of microglial cells and the expression of proinflammatory cytokines, suggesting further acceleration of neuroinflammation by reduction of brain Pls. A similar mechanism of Gnpat reduction was also found in human cell lines, triple-transgenic AD mouse brain, and postmortem human AD brain tissues. These findings suggest a novel mechanism of neuroinflammation that may explain prolonged progression of AD and help us to explore preventive and therapeutic strategies to treat neurodegenerative diseases.

Key words: c-Myc; Gnpat; neuroinflammation; NF- $\kappa \mathrm{B}$

\section{Significance Statement}

Ether-type glycerophospholipids, plasmalogens (Pls), are reduced in the brain of Alzheimer disease (AD) patients. We found that inflammatory stimuli reduced Pls contents by downregulation of the Pls-synthesizing enzyme glycerone phosphate 0 -acyltransferase (Gnpat) through NF- $\kappa$ B-mediated recruitment of c-Myc onto the Gnpat promoter in both murine and human cell lines. Murine brains after systemic lipopolysaccharide, chronic stress, and aging, as well as triple-transgenic AD mice and postmortem human $\mathrm{AD}$ brain tissues all showed increased c-Myc and reduced Gnpat expression. Interestingly, knockdown of Gnpat itself activated NF- $\kappa$ B in glial cell lines and microglia in mouse cortex. Our findings provide a new insight into the mechanism of neuroinflammation and may help to develop a novel therapeutic approach for neurodegenerative diseases such as AD.

\section{Introduction}

Plasmalogens (Pls) are unique glycerophospholipids containing a vinyl ether bond at the $s n-1$ position of the glycerol moiety; the well

\footnotetext{
Received Nov. 1, 2015; revised Feb. 20, 2017; accepted Feb. 21, 2017.

Author contributions: M.S.H., Y.F., and T.K. designed research; M.S.H., Y.A., F.A., M.Y., M.H., and T.K. performed research; T.K. contributed unpublished reagents/analytic tools; M.S.H., Y.A., and T.K. analyzed data; M.S.H. and T.K. wrote the paper.

This work was supported by the Japan Society for the Promotion of Science (KAKENHI Grant 26460320 to T.K. and Grant-in-Aid for Young Scientists Wakate B 16K19007 to M.S.H.). We thank Stephen Smale for kindly providing the p50 expressing vectors through the Addgene plasmid sharing service, Rhodri E. Jones (Kyushu University) and Ako Niwase for help with English, and the Research Support Center, Graduate School of Medical Sciences, Kyushu University, for technical assistance.

The authors declare no competing financial interests.

M. Youssef's present affiliation: Department of Animal Physiology, Faculty of Veterinary Medicine, South Valley University, Qena, 83523, Egypt.
}

known diacylglycerophospholipids such as phosphatidyl-ethanolamine, phosphatidyl-choline, and phosphatidyl-inositol have an ester bond at the same site. Pls are not only structural membrane components and reservoirs for second messengers, but are also involved in membrane fusion, ion transport, and cholesterol efflux (Farooqui and Horrocks, 2001). In addition, because the vinyl ether bond at the $s n-1$ makes Pls more susceptible to oxidative stress than corresponding ester-bonded glycerophospholipids, Pls act as antioxidants and protect cells from oxidative stress (Braverman and

Correspondence should be addressed to Toshihiko Katafuchi, M.D., Ph.D., Department of Integrative Physiology Graduate School of Medical Sciences, Kyushu University, 3-1-1, Maidashi, Higashi-ku, Fukuoka 812-8582, Japan. E-mail: kataf@physiol.med.kyushu-u.ac.jp.

DOl:10.1523/JNEUROSCI.3941-15.2017

Copyright $\odot 2017$ the authors $\quad 0270-6474 / 17 / 374074-19 \$ 15.00 / 0$ 
Moser, 2012). We have reported previously that Pls can suppress the lipopolysaccharide (LPS)-induced accumulation of $\beta$-amyloid protein $(\mathrm{A} \beta)$ and activation of glial cells in the hippocampus (Ifuku et al., 2012) and prevent neuronal cell death through the activation of AKT and ERK signaling (Hossain et al., 2013). More recently, Plssynthesizing enzyme (glycerone phosphate $\mathrm{O}$-acyltransferase, GNPAT) knock-out mice have been reported to show a reduction of AKT signaling in Schwann cells, resulting in defects in myelination (da Silva et al., 2014).

Although the accumulating evidence suggests that reduction of Pls, but not ester-type diacylglycerophospohlipids, in the brain of Alzheimer's disease (AD) patients can be a risk factor for this disease (Ginsberg et al., 1995; Guan et al., 1999; Han et al., 2001; Goodenowe et al., 2007; Hartmann et al., 2007; Grimm et al., 2011; Maeba et al., 2016), the mechanism behind the reduction of Pls remains elusive. It has been reported that inflammatory stimuli, stress, and aging activate NF- $\kappa \mathrm{B}$ in glial and neuronal cells, leading to neuroinflammation (O'Neill and Kaltschmidt, 1997; Mattson and Camandola, 2001; Chinta et al., 2013), which is known to be associated with neurodegenerative diseases including $\mathrm{AD}$ (Frank-Cannon et al., 2009; Amor et al., 2010). Here, we demonstrate that inflammatory signals, aging, and stress reduce the Pls levels in glial cells by the downregulation of Gnpat, which is mediated by the NF- $\kappa \mathrm{B}$-induced increase in recruitment of c-Myc onto the promoter region of the Gnpat gene. Furthermore, local knockdown of Gnpat alone can give rise to microglial activation both in vitro and in vivo accompanied by the enhanced expression of proinflammatory cytokines. More interestingly, the reduction of Gnpat and increase in c-Myc were also observed in the glial cells of postmortem AD human brains and in brain tissues from an $\mathrm{AD}$ mouse model. These findings suggest for the first time that the reduction of Pls, which is associated with inflammatory signals, aging, and stress, can be one of the causes behind the neuroinflammation process of the brain, which are mostly associated with the various neurodegenerative diseases including AD.

\section{Materials and Methods}

Animal, cell lines, and reagents. All of the animal experiments were conducted in accordance with the guidelines provided by the Committee on the Ethics of Animal Experiments, Kyushu University and performed in accordance with the Guidelines provided by the National Institutes of Health regarding the care and use of animals for experimental procedures. All efforts were made to minimize animals' suffering and the number of animals used for the study.

Male C57BJ6 mice (8 weeks or 16 months old as the aged group) were used for the in vivo study. For the chronic restraint stress (CRS) experiments, 7 adult male mice in each group were subjected to being immobilized in a tube for $2 \mathrm{~h} / \mathrm{d}$ for $10 \mathrm{~d}$. On the last day, $2 \mathrm{~h}$ after the stress, mice were killed for analysis. We used 18-month-old homozygous 3Tg-AD male mice, which had two familial AD-related gene mutations (AP$\mathrm{P}_{\mathrm{KM} 670 / 671 N \mathrm{~L}} / \mathrm{PS}_{\mathrm{M} 146 \mathrm{~V}}$ ) and a tau gene mutation $\left(\mathrm{Tau}_{\mathrm{P} 301 \mathrm{~L}}\right)$ (Oddo et al., 2003) and control mice of the same genetic background for the Western blotting and immunohistochemistry analysis (Billings et al., 2005). Mouse neuroblastoma-derived cells [Neuro2A (N2A), Riken Cell Bank catalog \#RCB2639, RRID: CVCL_0470], p53 knock-out mice derived astrocyte cell lines (A1, Japanese Collection of Research Bioresources IFO catalog \#IFO50519, RRID:CVCL_U223), the microglial cell lines (MG6, RCB catalog \#RCB2403, RRID: CVCL_8732), and the human embryonic kidney-derived cell lines (Hek293-T, RCB catalog \#RCB2202, RRID:CVCL_0063) were from Health Science Research Resources Bank. The human neuroblastoma-derived cell line SH-SY5Y was the gift of Dr. Yoshinori Katakura, Department of Bioscience and Biotechnology, Kyushu University. Cells were maintained in DMEM containing $10 \%$ heat-inactivated fetal bovine serum (FBS) (Invitrogen),
$50 \mu \mathrm{g} / \mathrm{ml}$ penicillin, $50 \mu \mathrm{g} / \mathrm{ml}$ streptomycin (Invitrogen), and glucose at $37^{\circ} \mathrm{C}$ in $5 \% \mathrm{CO}_{2}$ as described previously (Hossain et al., 2013). Primary hippocampal neurons were prepared from embryonic day 18 (E18) mice. After dissection of anesthetized pregnant mice, meninges of the embryo were removed carefully. The hippocampi were cleared with the surrounding cortex and dissolved in trypsin solution containing PBS, bovine serum albumin (BSA), and glucose at $37^{\circ} \mathrm{C}$ for $15 \mathrm{~min}$. FBS was used to neutralize trypsin activity. The hippocampi were then dissociated in neurobasal medium (Invitrogen) supplemented with B27 (Invitrogen) by appropriate pipetting using different pore-sized Pasteur pipettes. The dissociated neurons were then cultured on poly-D-lysine-coated glass coverslips ( 30,000 cells $/ 15 \mathrm{~mm}$ coverslip) with neurobasal medium in a $5 \% \mathrm{CO}_{2}$ humidified incubator. On d in vitro 3 (DIV3), $90 \%$ of cultured medium was replaced with B27-free neurobasal medium. Cytosine arabinoside (Ara-C) from Sigma-Aldrich was added on DIV3 primary neurons at a concentration of $1 \mu \mathrm{M}$ to inhibit microglial proliferation. More than $95 \%$ pure primary hippocampal pyramidal neuronal cells (on D21) were used as primary neurons (Hossain et al., 2013). Primary microglia ( $>90 \%$ pure) and astrocytes ( $>85 \%$ pure) were collected according to our previous report (Ifuku et al., 2014) from the hippocampal tissue of newborn mice. Purity data are available upon request. LPS, polyriboinosinic:polyribocytidylic acid (Poly I:C), and recombinant interleukin-1 $\beta$ (IL-1 $\beta$ ) were from Sigma-Aldrich.

Real-time PCR analyses. Total RNA was extracted from cells and tissues using TRIZOL reagents (Life Technologies) following standard protocols. cDNAs were prepared from the purified total RNA using ReverTra Ace qPCR RT Kit (Toyobo). Real-time PCR was performed by SYBR Premix Ex Taq (RR420Q; Takara) following the manufacturer's protocol. The quantifications were performed by 7500 Real Time PCR System software version 2.0 (Applied Biosystems). The specific primers used to amplify the each mouse gene from the cDNA were as follows: Gnpat, forward $5^{\prime}$-TCC TGGGAATGAGAGTGGTC-3' and reverse $5^{\prime}$-TTCAGAGAATACGGCCCAGT-3'; IL-1 $\beta$, forward 5'-AAAGCTCTCCACCTCAATGG-3' and reverse 5'-AGGCCACAGGTATTTTGTCG-3'; Mcp-1, forward 5'-AGGTC CCTGTCATGCTTCTG-3' and reverse $5^{\prime}$-TGGGATCATCTTGCTGGTGA-3'; TNF- $\alpha$, forward 5'-AAGCCTGTAGCCCACGTCGT-3 and reverse $5^{\prime}$-AGGTACAACCCATCGGCTGG-3'; Igf-1, forward 5'-AG CAACTGTGTAGAGGTGGT-3 and reverse $5^{\prime}$-AGGGTGTGTCTAATGCAGCT-3'; P2Y12 receptor, forward 5'-AGTATTCCCGGAGACACTC-3 and reverse $5^{\prime}$-AGAAGGTGGTATTGGCTGAG-3'; Tgf- $\beta$, forward $5^{\prime}$ CTCTCCACCTGCAAGACCAT-3' and reverse 5'-GCGAGCCTTAGT TTGGACAG-3'; $c$-Myc, forward 5'-AGATCAGCAACAACCGCAAG-3' and reverse 5'-GTTCCTCCTCTGACGTTCCA-3'; Mycn, forward 5' AACAACCAAGGCGGTAACCAC- $3^{\prime}$ and reverse $5^{\prime}$-GAACACAGCGCTTGAGGATC- $3^{\prime}$; Tlr4, forward $5^{\prime}$-TCCCTGATGACATTCCTTCTT-3' and reverse 5'-TGAGCCACATTGAGTTTCTTTA-3'; Tlr3, forward 5' -ACTTGCTATCTTGGATGC-3' and reverse 5'-AGTTCTTCACTTCGCAAC-3'; p65, forward 5'-CACCGGATTGAAGAGAAGCG-3' and reverse 5'AGTTGAGTTTCGGGTAGGCA-3'; $\beta$-Actin, forward $5^{\prime}$-CACTGTGCCCATCTACGA- $3^{\prime}$ and reverse $5^{\prime}$-CAGGATTCCATACCCAAG- ${ }^{\prime}$.

Western blotting assays. For whole lysates, cells were washed in ice-cold PBS and lysed using RIPA buffer (1\% NP40, 0.5\% sodium deoxycholate, and $0.1 \%$ SDS dissolved in $1 \times$ TBS) mixed with the complete protease inhibitor cocktail tablets (Roche). After $30 \mathrm{~min}$ on ice with the lysis buffer, cells were subjected to brief sonication at $4^{\circ} \mathrm{C}$, followed by centrifugation at 15,000 rpm for $10 \mathrm{~min}$ to remove insoluble cell debris. For subcellular fractionation assays, cells were suspended in mild buffer (0.5\% NP40, $1 \mathrm{~mm}$ EDTA, and $10 \mathrm{~mm}$ Tris- $\mathrm{HCl})$, followed by centrifugation at 15,000 rpm, and the supernatant (cytoplasmic fraction) was collected. The precipitate was then washed three times in the same mild buffer and dissolved with RIPA buffer to collect the nuclear fraction. Protein concentration was measured by the BCA protein assay kit (Thermo Scientific) and a total of $20 \mu \mathrm{g}$ of protein was loaded for analysis by SDS-PAGE. After the protein transfer, nitrocellulose membranes (Bio-Rad) were blocked with Tris-buffered saline containing 5\% Difco skim milk (BD Biosciences) and $0.1 \%$ Tween 20 for $1 \mathrm{~h}$ at room temperature. Membranes were then incubated at $4^{\circ} \mathrm{C}$ overnight with antibodies against GNPAT (Abcam catalog \#ab75060 RRID:AB_2232364), c-MYC (Santa Cruz Biotechnology catalog \#sc-764 RRID:AB_631276), Mycn 
A

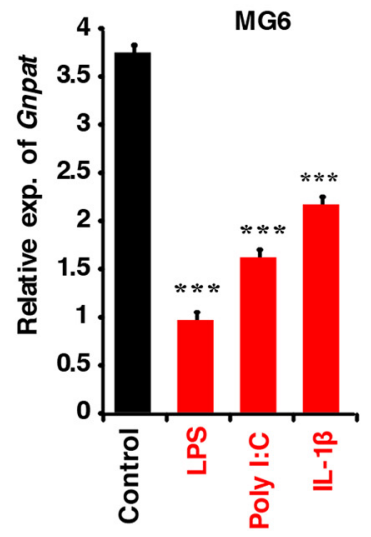

B

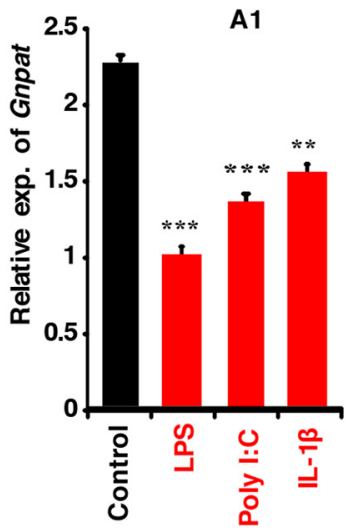

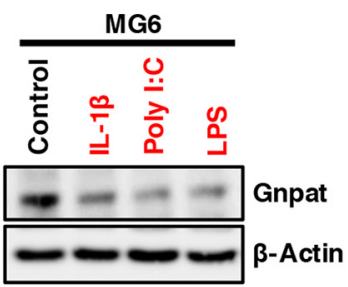

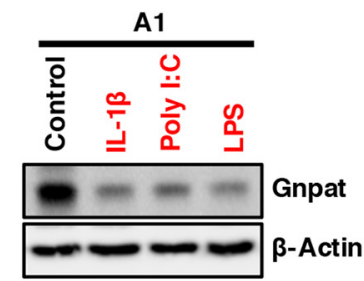

C
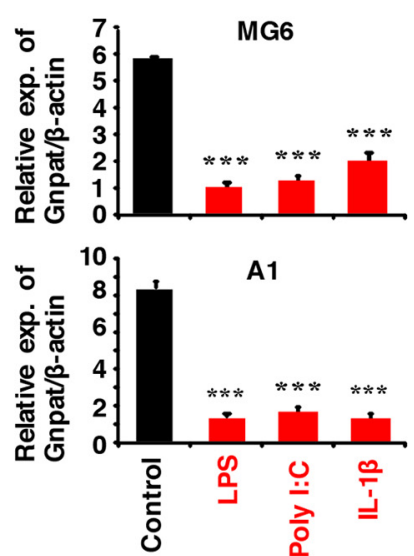

D

$95-100 \% 85-95 \% 70-85 \% 50-70 \%<50 \%$

MG6 cells

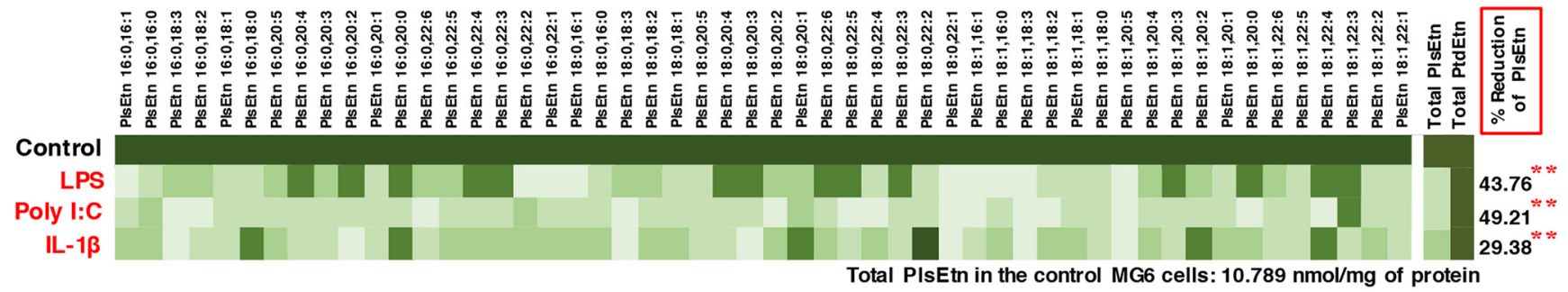

E

A1 cells

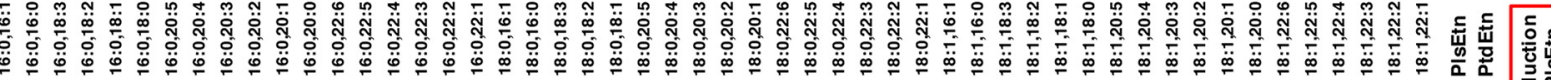

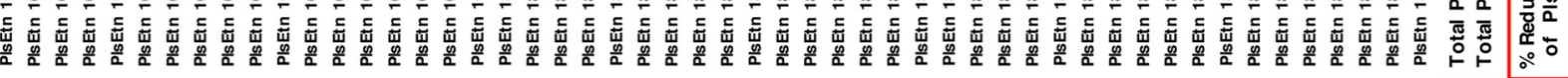

\section{Control}

Poly I:C

IL-1 $1 \beta$

F

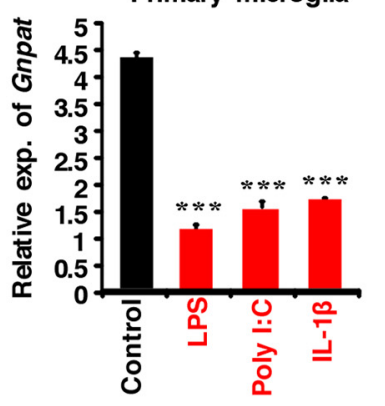

G

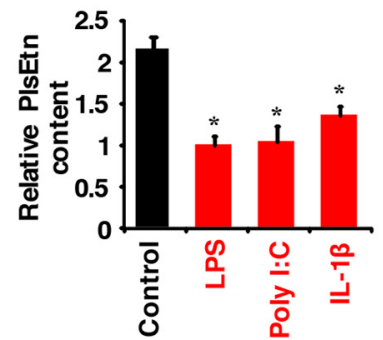

Primary astrocytes
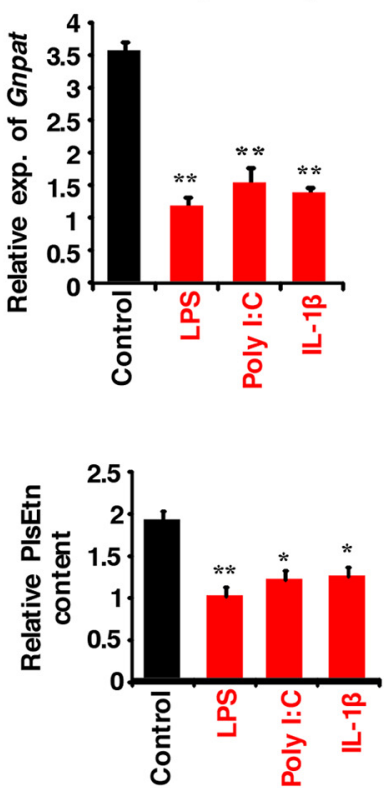

H

Primary microglia

Primary astrocytes
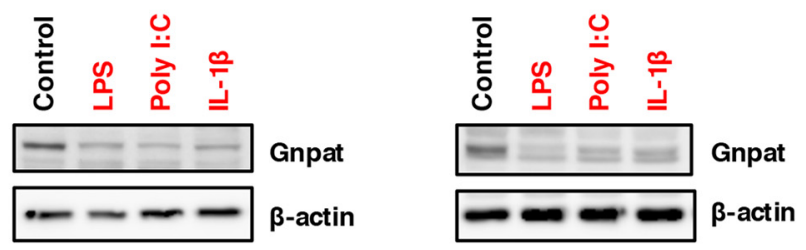

I

Primary neurons
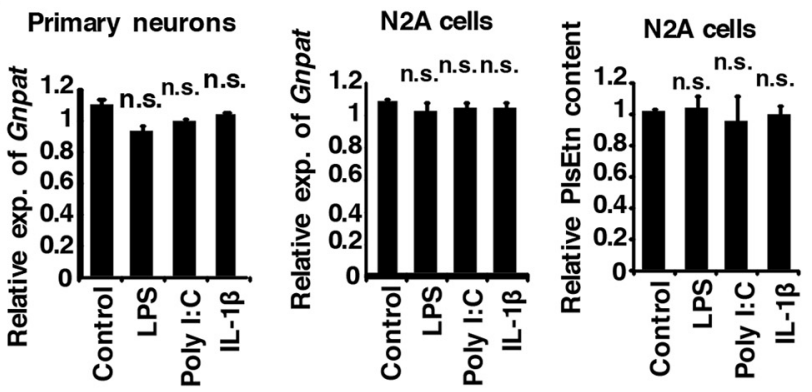
(Calbiochem catalog \#GTX16898 RRID:AB_422464), p65 (Cell Signaling Technology catalog \#6956 also 6956S RRID:AB_10828935), Lamin A (BD Biosciences catalog \#612162 RRID:AB_399533), Flag tag (MBL catalog \#M185-3L RRID:AB_11123930), and $\beta$-Actin (Cell Signaling Technology catalog \#sc-47778 RRID:AB_626632). After the addition of the primary antibodies, membranes were washed and then incubated with horseraplate peroxidase-coupled goat anti-mouse or anti-rabbit IgG secondary antibody (Cell Signaling Technology) at room temperature for $2 \mathrm{~h}$. Specific signals from the transferred protein were then visualized by SuperSignal West Pico Chemiluminescent Substrate (Thermo Scientific) using a LAS4000 biomolecular imager. ImageJ software was used to quantify the signals.

Liquid chromatography (LC), electron spray ionization (ESI), and -tandem mass spectrometry (MS) assays. Extraction of the total lipids was performed using the method of Bligh and Dyer (Bligh and Dyer, 1959; Abe et al., 2014). Briefly, the cells and tissues were dissolved in PBS, followed by sonication in ice-cold water. After determining the protein concentration, an equal amount $(50 \mu \mathrm{g})$ of protein was dissolved in methanol/chloroform/water (v/v/v: 2:1:0.8) and 50 pmol internal standard (1-heptadecanoylsn-glycero-3-phosphocholine, 1, 2-didodecanoyl-sn-glycero-3-phosphocholine and 1,2-didodecanoyl-sn-glycero-3phosphoethanolamine). After $5 \mathrm{~min}, 1 \mathrm{ml}$ each of water and chloroform was added and the mixture was centrifuged to collect the lower organic phase. Next, $1 \mathrm{ml}$ of chloroform was added to reextract the lipids. The collected organic phase was then evaporated under a nitrogen stream and suspended in pure methanol. The LC-MS assay was performed using a 4000 Q-TRAP quadrupole linear ion trap hybrid mass Q8 spectrometer (AB Sciex) with the ACQUITY UPLC System (Waters). Samples were injected to an ACQUIRY UPLC BEH C18 column and then subjected directly to ESI-MS/MS analysis. A $10 \mu \mathrm{l}$ aliquot of each sample was directly introduced by autosampler injector and the samples were separated by step gradient elution with mobile phase A (acetonitrile:methanol:water at 2:2:1 (v/v/v), 0.1\% formic acid and 0.028\% ammonium) and mobile phase B (isopropanol, $0.1 \%$ formic acid and $0.028 \%$ ammonium) at the following ratios: 100:0 (for 0-5 $\mathrm{min}$ ), 95:5 (5-20 $\mathrm{min}$ ), 70:30 (20-21 min), 50:50 (21-45 min), 50:50 (45-100 min), and 100:0 (100$120 \mathrm{~min})$. The flow rate $\left(70 \mu \mathrm{l} / \mathrm{min}\right.$ at $\left.30^{\circ} \mathrm{C}\right)$, source temperature $\left(200^{\circ} \mathrm{C}\right)$, declustering potential $(60)$, and collision cell exit potential $(15)$ were kept constant. Ethanolamine Pls (PlsEtns) with alkenyl p16:0, $\mathrm{p} 18: 0$, and p18:1 at the sn-1 position was detected by precursor ion scan of $\mathrm{m} / z$ 364, 392, and $\mathrm{m} / z 390$, respectively, in positive ion mode. The data were analyzed and quantified using Analyst software (AB Sciex).

Cloning of promoter constructs and luciferase reporter assays. Genomic DNA near the first exon of the mouse GNPAT gene $(-1000 /+226)$ and the human GNPAT gene $(-966 /+288)$ were amplified from mouse embryonic genomic DNA and human-derived cell line (Hek-293T) genomic DNA, respectively, by PCR using LA-Taq polymerase (Takara). The PCR products were then cloned into the pGEM-T Easy Vector System 1 (Promega) and sequenced. By using the T-vector as a template DNA, the luciferase constructs were cloned into the EcoR1-digested pBV-Luc vector (Addgene plasmid 16539; He et al., 1999) with the Infusion HD cloning kit (Takara). The following primers were used for mouse Gnpat promoters, mGnpat-700FW: 5-CGTCGATATCGAATTAAGTGTTGTCGGTGG-3, mGnpat-150FW:

Figure 1. Downregulation of Gnpat by LPS, Poly I:C, and IL-1 $\beta$ in glial cells but not in neuronal cells. $A$, Real-time PCR data showing the reduction of Gnpat mRNA expression in MG6 and A1 cells treated with LPS $(10 \mu \mathrm{g} / \mathrm{ml})$, Poly l:C $(10 \mu \mathrm{g} / \mathrm{ml})$, and IL-1 $\beta(20 \mathrm{ng} / \mathrm{ml})$ for $6 \mathrm{~h}$. $B$, Western blot data show the reduction of Gnpat protein by treatment with inflammatory stimuli as in the same condition of $\boldsymbol{A}$. C, Quantification of the Western blot images in $\boldsymbol{B}$. $\boldsymbol{D}, \boldsymbol{E}$, LC-MS analysis showing the reduction of PIsEtn species in MG6 $(\boldsymbol{D})$ and A1 $(\boldsymbol{E})$ cells after inflammatory treatments for $12 \mathrm{~h} . \boldsymbol{F}, \boldsymbol{G}$, In similar experimental conditions to $A$, the LPS-Poly I:Cand IL-1 $\beta$-induced decreases in Gnpat mRNA expression and total PIsEtn were also observed in mice primary microglial and astrocytes. $\boldsymbol{H}$, Reduction of protein expression of Gnpat in the primary microglial and astrocytes by similar treatment with ainflammatory agents as in $\mathbf{A}$. $\boldsymbol{I}$, Similar treatments with LPS, Poly I:C, and IL-1 $\beta$ failed to reduce Gnpat expression in mice primary neurons and N2A cells (top) and PIs-Etn content in N2A cells (bottom). The data represent four independent experiments. ${ }^{* *} p<0.01 ;{ }^{* * *} p<0.001$.
5-CGTCGATATCGAATTACCCAGGTCGTAGAG-3 and mGnpat +226RV: TTATATACCCGAATTGGAGGAGCTAGGAAC-3. For the human GNPAT promoters hGNPAT -400 forward: 5'-CGTCGATATCG AATTTACAAGCAAGTAGGATGGTC-3' hGNPAT - 150 forward: $5^{\prime}$ CGTCGATATCGAATTCCAAAGTCGTAAAGGTTCTGG- ${ }^{\prime}$ and hGN PAT + 183 reverse: 5'-TTATATACCCGAATTCGGTCTGGGATT CTTTGCTAAGCC-3' For infusion ligation, the underlined sequences were for ligation into the EcoR1-digested pBV-Luc vectors. Two Myc sites $(+70$ and +121 )-deleted mouse promoter constructs were performed by PCR amplification of the whole vector using the primers 5-AGATGGCGGTGCCCGGGGT(CCCGTG)CAGTGGCCGTACGGAGTGCC-3 and 5-TG GGCAGACGGGAGCCGC(CCCGTG)CGAAAGAACCGCCCCCAG-3. The underlined Myc binding sequences were deleted. The cells were seeded in the 96 -well plate (2000 cells/well), followed by the transfection of Gnpat promoter constructs (100 ng) with or without the expressing plasmids p65 (Addgene plasmid 20012; Sanjabi et al., 2005) and p50 (Addgene plasmid 20018) with Fugene-HD (Promega) and viruses derived from the vectors [c-MYC (Addgene plasmid 20324; Brambrink et al., 2008) and N-MYC (Addgene plasmid 15951; Blelloch et al., 2007). After the $48 \mathrm{~h}$ transfection and infection period with lentiviruses (as described in the "Preparation of sh-RNA lentiviruses and in vivo injection into mouse brain" section), luciferase activities were measured by the luciferase assay kit (Promega).

ChIP assays. ChIP assays were conducted as described previously (Hossain et al., 2008; Hossain et al., 2012). In brief, cells or tissues were cross-linked with $1 \%$ formaldehyde in PBS for $10 \mathrm{~min}$ at $37^{\circ} \mathrm{C}$. ChIP was performed following the protocol of Millipore's ChIP Assay Kit. Briefly, the cross-linked chromatin was sonicated to an average length of 200-300 nt and cleaned with protein A-agarose beads pretreated with shared salmon sperm DNA. The chromatin fragments were then mmunoprecipitated with rabbit anti-cMYC (sc-764; Santa Cruz Biotechnology) and mouse anti-Mycn (NCM II 100; Calbiochem) antibodies conjugated with protein A-agarose. After washing, the immunoprecipitates were eluted with $200 \mu \mathrm{l}$ of elution buffer $\left(1 \% \mathrm{SDS}\right.$ and $0.1 \mathrm{M} \mathrm{NaHCO}_{3}$ ). Cross-links were reversed by heating at $65^{\circ} \mathrm{C}$ for $5 \mathrm{~h}$ and the samples were treated with proteinase $\mathrm{K}$ at $45^{\circ} \mathrm{C}$ for $1.5 \mathrm{~h}$. The precipitated DNA and control input DNA was purified using the extraction kit (K210012; Invitrogen). Amplification of the DNA was performed using conventional PCR with rTaq DNA polymerase (R001A; Takara) by the primers forward: $5^{\prime}$-CCTGGTTAAGATGGCGGTGC- ${ }^{\prime}$ and reverse: $5^{\prime}$ GGTCTGCTACACGGCTGTA-3' for the Myc binding sites onto the mouse Gnpat promoter region $(+43$ to +171$)$; forward: $5^{\prime}$-ATTTGGCCGTAT TGGGCGCCT-3' and reverse: $5^{\prime}$-CTTCCCATTCTCGGCCTTGACT GT-3' for the input control of mice Gapdh genomic region; forward-250: 5'-CCTTTAGCCTCAAAGCAGAGG-3' and reverse-130: 5'-CCAGAACCTTTACGACTTTGG- 3 ' for the MYC binding sites ( -178 of the first exon) onto the human GNPAT promoter region; and forward: 5'-GTTTTACGGGCGCACGTAGCTCA-3' and reverse: $5^{\prime}$-CTGGCGACGCAAAAGAAGATG-3' for the input control of human GAPDH promoter region.

Preparation of sh-RNA lentiviruses and in vivo injection into mouse brain. The sh-RNA sequences were cloned into the pLL3.7 lentiviral vector following the protocol provided on the Addgene website (plasmid 11795; Rubinson et al., 2003). The target sequences were as follows: sh-Gnpat \#1 (5'-GTCCCAATTAGCATCAGT-3'), sh-Gnpat \#2 (5'-GGCTCAATCGGAACACGT-3'), sh-c-Myc (5'-CACAACGTCTTGGAACGT-3') and shLuc (5'-CTTACGCTGAGTACTTCGAG-3'). For the viral constructs, Hek-293T cells were transfected with the cloned pLL3.7 vectors along with the vectors pMD2.G (Addgene plasmid 12259), pRSV-Rev (Addgene plasmid 12253), and pMDLg/pRRE (Addgene plasmid 12251). The cell supernatant was centrifuged at $24,000 \mathrm{rpm}$ for $3 \mathrm{~h}$ at $4^{\circ} \mathrm{C}$ and the viral pellet was dissolved in PBS ( $1 \%$ BSA). After determining the viral titer in N2A cells, $5 \times$ $10^{5}$ transduction units were injected into the cortical region of mouse brain using a stereotaxic apparatus (injection rate: $0.05 \mu \mathrm{l} / \mathrm{min}$ ). The stereotaxic coordination of the cortex was: A $0.67 \mathrm{~mm}, \mathrm{~L} 1.80 \mathrm{~mm}$, and $\mathrm{H} 1.65$ $\mathrm{mm}$. After the injection, the wound was sutured and antibiotics were applied. Two weeks after the injection, the mouse brains were analyzed using immunohistochemistry.

Immunohistochemical staining. To prepare the cryosections, mice were perfused intracardially with PBS followed by $4 \%$ PFA solution. The brains were then collected in $4 \%$ PFA solution and kept overnight at $4^{\circ} \mathrm{C}$, followed 
A

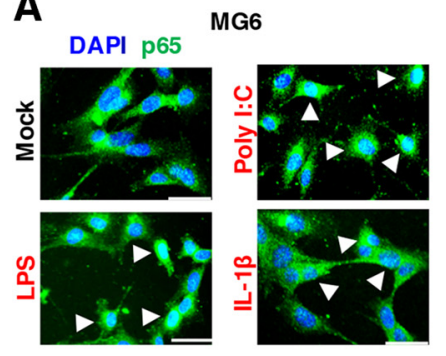

C

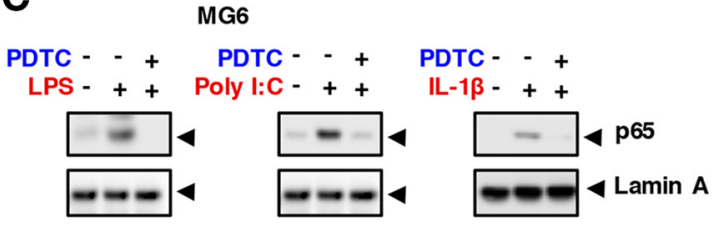

E
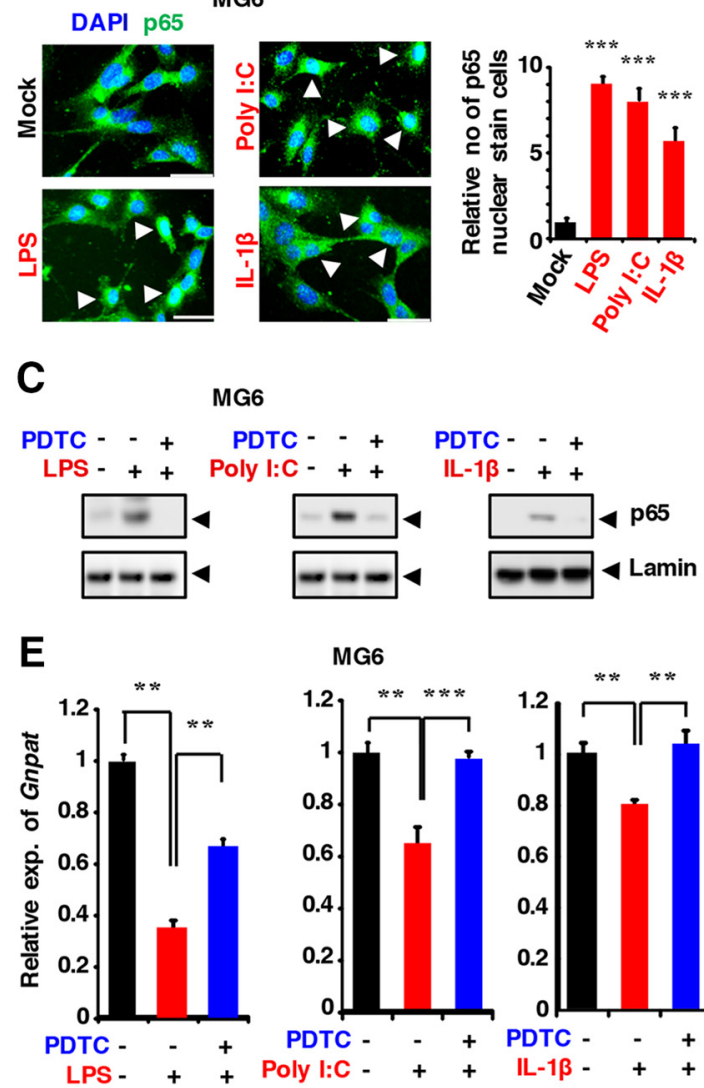

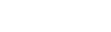

D

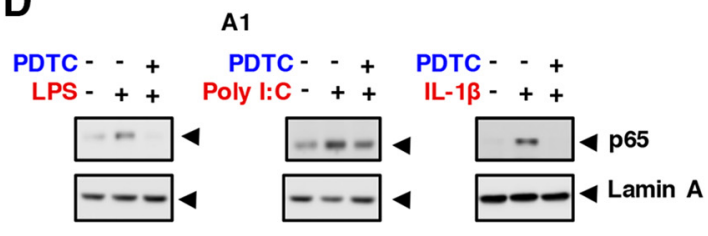

F
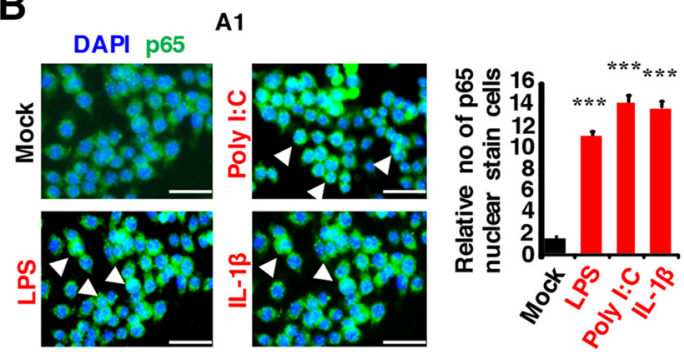

D

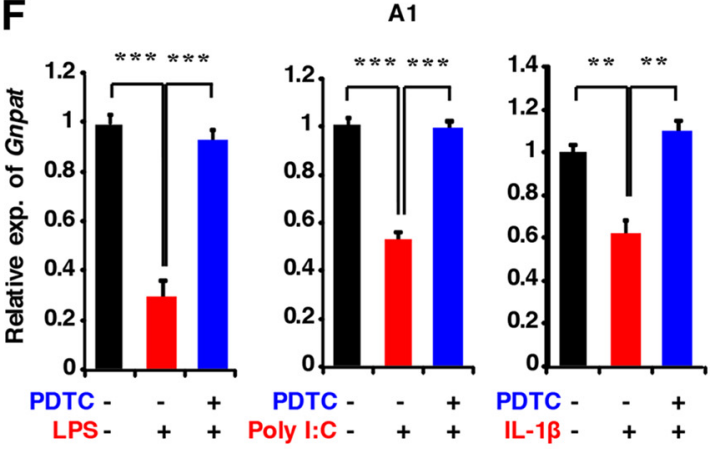

G

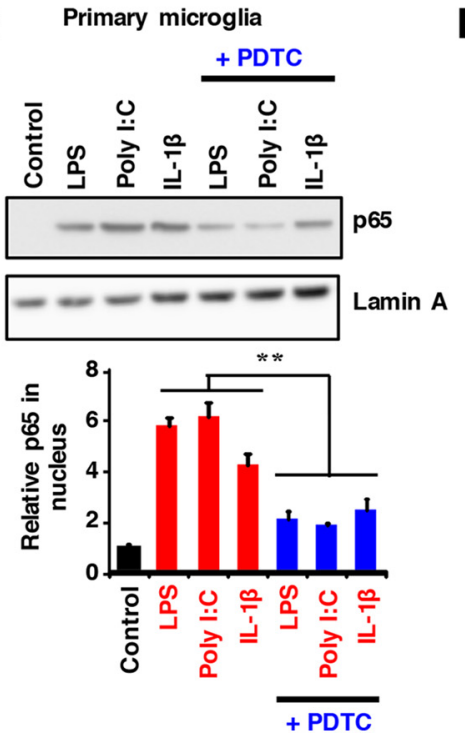

H Primary astrocytes
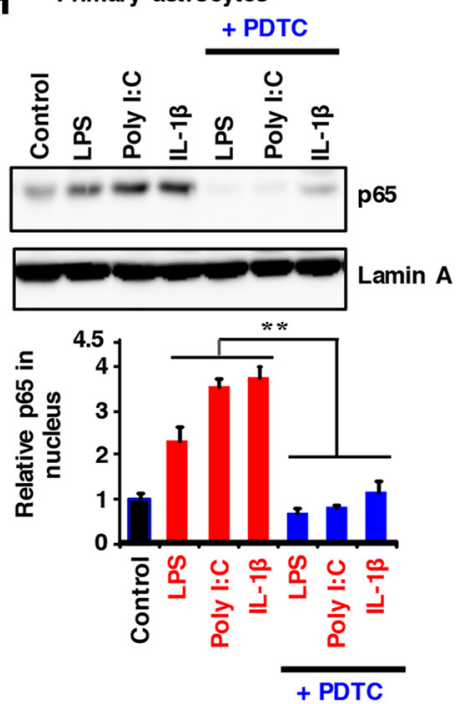

I
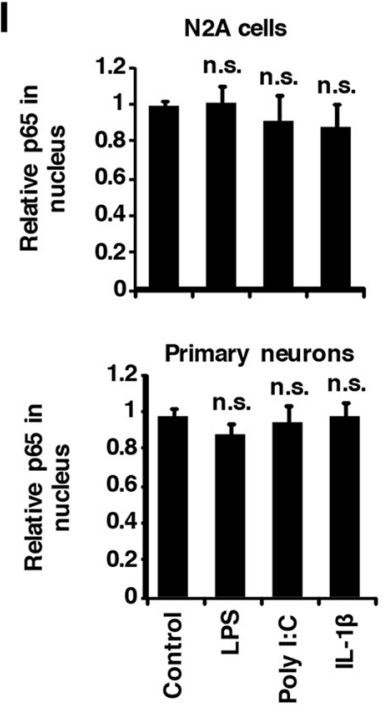

Figure 2. NF- $\kappa B$ activation-induced downregulation of GNPAT in glial cells. $A, B$, Increase in the nuclear localization of p65 by LPS, Poly l:C, and IL-1 $\beta$ treatments (arrowheads) in MG6 ( $A$ ) and A1 (B) cells. Scale bar, $20 \mu \mathrm{m} .{ }^{* * *} p<0.001$. C, D, Western blot data with the nuclear fractionation samples of MG6 cells (C) and A1 cells (D) pretreated with an NF- $\kappa B$ inhibitor, PDTC ( $\left.50 \mu g / m l\right)$, for $30 \mathrm{~min}$ followed by LPS, Poly I:C, and IL- $1 \beta$ treatments for $2 \mathrm{~h}$. E, $F$, Real-time PCR data showing the attenuation of inflammatory stimuli-induced downregulation of $G n p a t$ by pretreatment with PDTC ( $50 \mu \mathrm{g} / \mathrm{ml}, 30 \mathrm{~min})$ in MG6 (E) and A1 (F) cells. $\boldsymbol{G}, \boldsymbol{H}$, Treatments with LPS, Poly I:C, and IL-1 $\beta$ also increased nuclear p65 expression in primary microglia and astrocytes that were reduced by the PDTC treatments. $I$, Nuclear $p 65$ was unchanged by the same treatments in N2A (top) and mouse primary neurons (bottom). ${ }^{* *} p<0.01 ;{ }^{* * *} p<0.001(n=4)$.

by embedded in optimal cutting temperature compound. The brains were then stored at $-80^{\circ} \mathrm{C}$ before making thin sections ( $30 \mu \mathrm{m}$ thick). Sections were collected in ice-cold PBS and treated to $3 \mathrm{~N} \mathrm{HCl} \mathrm{for} 30 \mathrm{~min}$, followed by extensive washing with PBS on a shaker. After $1 \mathrm{~h}$ of treatment with a blocking solution $(0.2 \%$ Triton X-100 + 5\% BSA dissolved in PBS), tissue slices were incubated with the antibodies dissolved in the same blocking solution overnight at $4^{\circ} \mathrm{C}$ on a shaker. The following antibody dilutions were used:
Iba-1 (1:10,000; Sigma-Aldrich), goat Iba-1 Cy3 conjugated GFAP (1:4000; Sigma-Aldrich catalog \#C9205 RRID:AB_476889), NeuN (1:1000; Millipore), c-MYC (1:500; Santa Cruz Biotechnology catalog \#sc-764 RRID: AB_631276), p65 (1:1000; Cell Signaling Technology catalog \#6956 also 6956S RRID:AB_10828935), and GNPAT (1:500; Abcam catalog \#ab75060 RRID:AB_2232364). After brief washing in PBS, the brain slices were incubated with fluorochrome-conjugated secondary antibodies (1:1000 in 
A

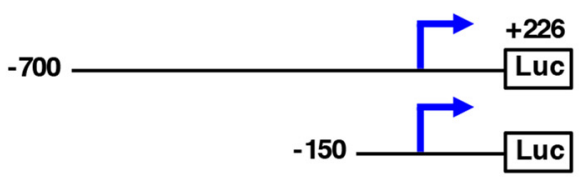

C

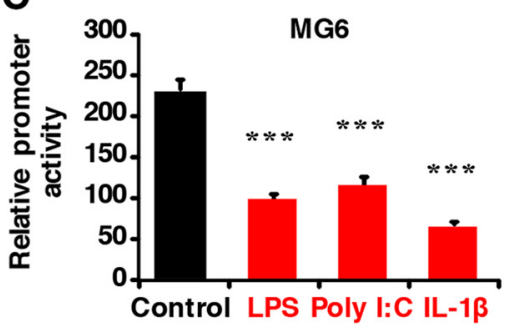

B

Relative Luciferase Activity
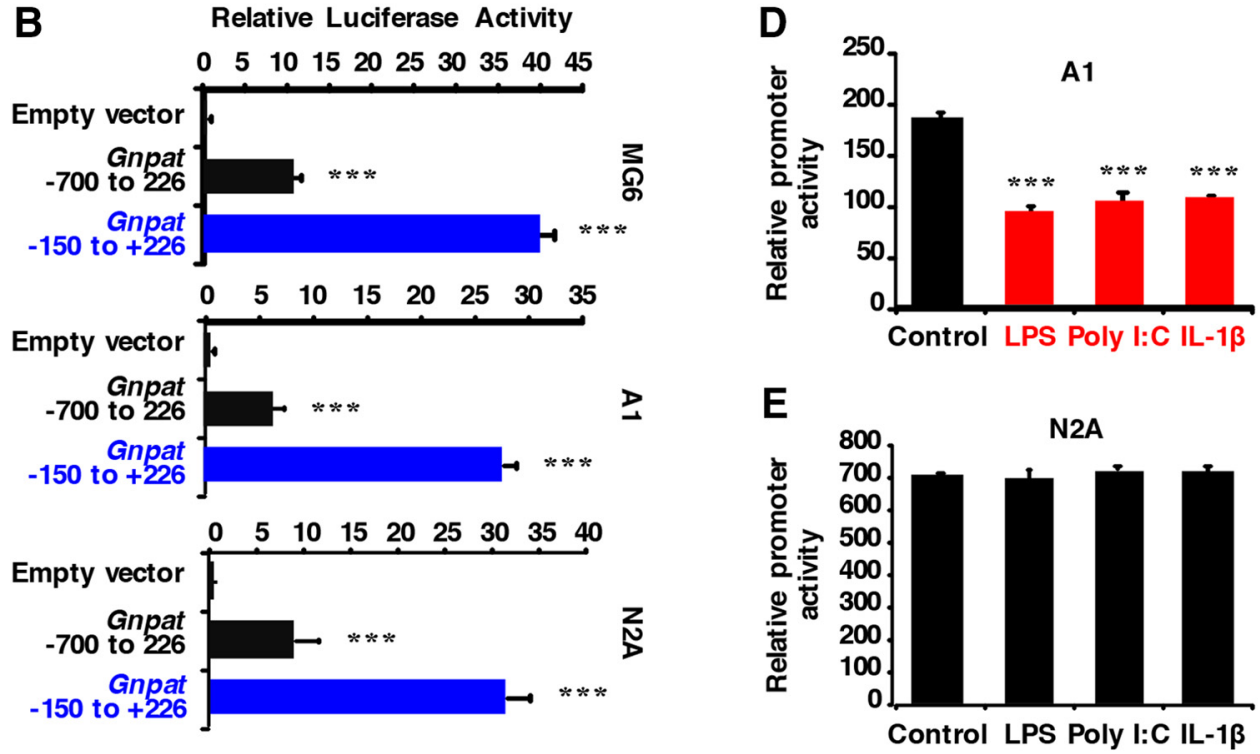

$\mathbf{F}$

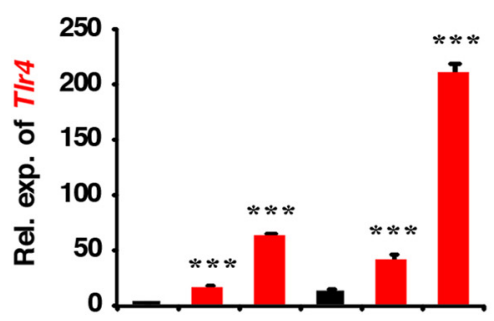

H

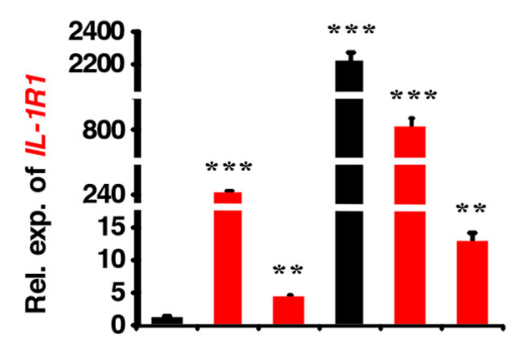

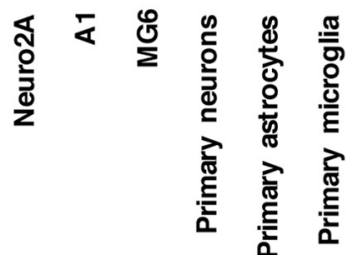

G

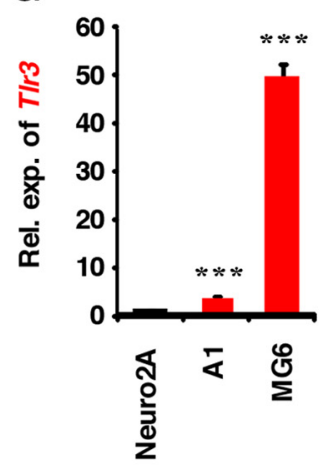

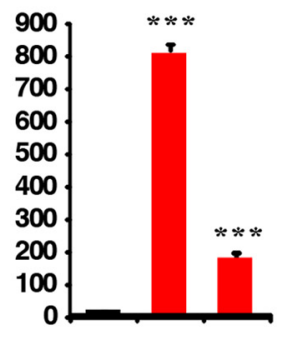

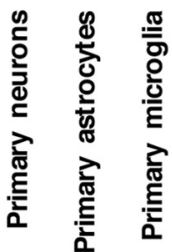

Figure 3. Gnpat promoter activity and endogenous expression of $T / r 4, T / r 3$, and $/ L-R 7$ in neurons and glial cells. $A$, Two possible promoter regions upstream of the Gnpat first exon were cloned into the luciferase vector. $\boldsymbol{B}$, Promoter activity of the luciferase vectors was examined in the indicated cells $48 \mathrm{~h}$ after transfection ( $100 \mathrm{ng}$ vectors/2000 cells/well in 96 well platees). $\boldsymbol{C}-\boldsymbol{E}$, Forty-two hours after Gnpat core promoter $(-150$ to +226$)$ luciferase vector transfection, the indicated cells were treated with the same dose of LPS, Poly I:C, and IL-1 $\beta$ as in Figure 1 for 
A

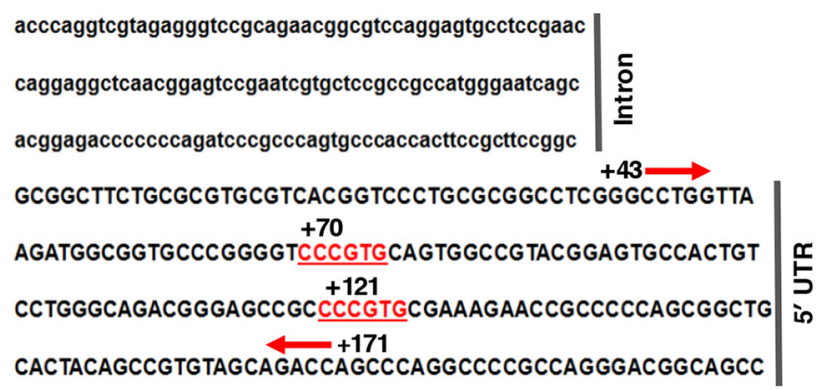

GCGCCATGGACGTTCCTAGCTCCTCC

Translation start site
B

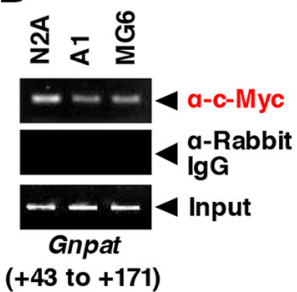

\section{똔 in}

D

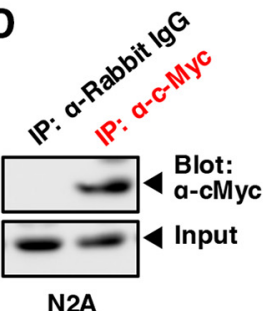

G
C

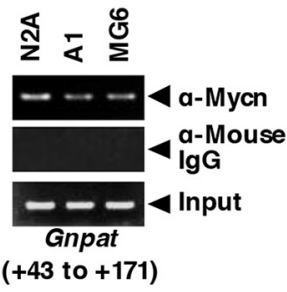

E

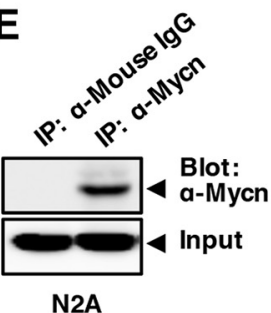

$\mathbf{F}$

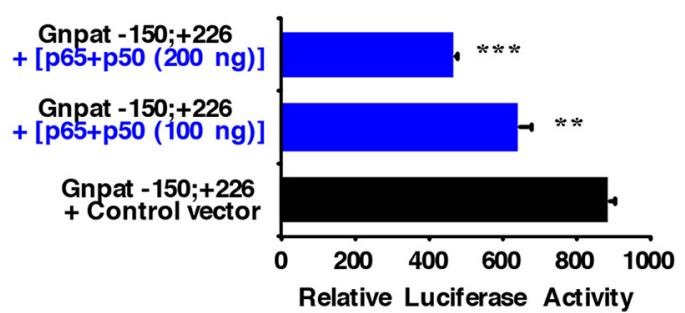

N2A

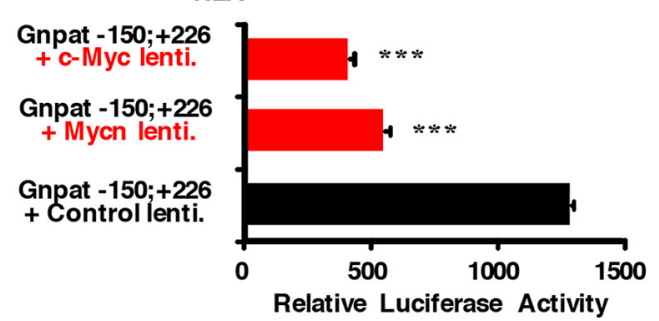

Figure 4. Recruitment of NF- $\kappa$ B and Myc proteins onto the Gnpat promoter. $\boldsymbol{A}$, Two possible Myc protein-binding sequences onto the mouse Gnpat promoter region are shown in red. $\boldsymbol{B}, \boldsymbol{C}$, ChIP assays show the basal recruitment of $\mathrm{C}-\operatorname{Myc}(\boldsymbol{B})$ and $\operatorname{Mycn}(\boldsymbol{C})$ onto the Gnpat promoter ( +43 to +171$)$ in the indicated cultured cells. $\boldsymbol{D}, \boldsymbol{E}$, Immunoprecipitation (IP) data showing specific pull-down of $c-\operatorname{Myc}(\boldsymbol{D})$ and Mycn $(\boldsymbol{E})$ by the antibodies. $\boldsymbol{F}$, Promoter assays show the reduction of Gnpat promoter activity $48 \mathrm{~h}$ after NF- $\kappa \mathrm{B}$ (p65 $+\mathrm{p} 55$ )-expressing lentiviruses $\left(1 \times 10^{5}\right.$ transduction units/2000 cells/well of 96 -well plate) infection. N2A cells were previously transfected with the luciferase promoter vectors (100 ng/2000 cells/well in 96 -well plate). $\mathbf{G}$, Luciferase promoter assays showing that overexpression of c-Myc and Mycn by lentiviral vectors (100 ng each) reduced the Gnpat promoter activity.

blocking solution; Alexa Fluor 488/568; Life Technologies) for $3 \mathrm{~h}$ at room temperature. DAPI was used for nuclear staining. For the amyloid $\beta$ staining of 3Tg mice brain tissue, the standard DAB staining protocols provided with the kits (Vectastain ABC kit PK-6200 and ImmPACT DAB kit SK-4105 of Vectro) for the amyloid $\beta$ polyclonal antibody (Abcam catalog \#ab2539 RRID:AB_303141) were used. To detect the glial expression of c-MYC and GNPAT,paraffin tissue panels of the human postmortem brains from BioChain (catalog \#T8236446Alz) were used. Photographs of all the stained samples were taken with a KEYENCE (BZ-9000) fluorescence microscope.

Statistics. To analyze the statistical significance between experimental groups, one-way ANOVA followed by a post hoc test (Bonferroni's test) were performed. The data are presented as mean \pm SEM. $p<0.05$ was considered significant.

\section{Results}

Inflammatory stimuli reduce Pls levels through the activation of NF- $\kappa \mathrm{B}$ in glial cells

To understand the critical process of Pls reduction in the brain, we challenged microglial (MG6) and astrocyte (A1) cell lines with major inflammatory stimuli, LPS, Poly I:C, and IL- $1 \beta$ and found a significant reduction in both mRNA and protein expression of a Pls-synthesizing enzyme, Gnpat (Fig. $1 A-C$ ). Consistent with these results, LC-MS assays showed a significant reduction of

$\leftarrow$

additional $6 \mathrm{~h}$, followed by the luciferase assays. $\boldsymbol{F}, \boldsymbol{G}$, Real-time $P C R$ data showing the increased expression of $T / r 4(\boldsymbol{F})$ and $T / r 3(\boldsymbol{G})$ among glial cells compared with neuronal cells. $\boldsymbol{H}$, Expression of $I L-1 R$ was higher in the glial cell lines compared with N2A, but the primary neurons had abandoned expression for IL-1R. ${ }^{* *} p<0.01 ;{ }^{* * *} p<0.001(n=5)$.
PlsEtn, which was more abundant than choline Pls in the brain (Farooqui and Horrocks, 2001), in the MG6 (Fig. 1D) and A1 (Fig. $1 E$ ) cells after these stimuli $(p<0.01)$. We also observed a reduction of Gnpat mRNA and of total Pls in primary microglia and astrocytes after exposure to LPS, Poly I:C, and IL- $1 \beta$ (Fig. $1 F, G)$. There was also a reduction of GNPAT protein expression by inflammatory agents in the primary microglial and astrocytes (Fig. $1 H$ ). However, Gnpat mRNA and Pls content failed to decrease in the primary neurons and neuronal cell line N2A cells by these stimuli (Fig. 1I).

The activation of NF- $\kappa \mathrm{B}$ is often characterized by nuclear localization of its major subunits, p65 or p50, in the brain (O'Neill and Kaltschmidt, 1997; Mattson and Camandola, 2001). Therefore, we investigated activation in our experimental conditions and confirmed that all of the inflammatory stimuli used increased the nuclear translocation of p65 in the MG6 (Fig. 2A) and A1 (2B) cells. Pretreatment with an NF- $\kappa$ B inhibitor, PDTC (Zhou et al., 1999), inhibited nuclear localization of p65 (Fig. 2C,D). In addition, the LPS-, Poly I:C-and IL-1 $\beta$-induced reduction of Gnpat expression was attenuated by pretreatment with PDTC (Fig. $2 E, F)$. Similar results as found in the cell lines were also obtained with primary microglia (Fig. $2 \mathrm{G}$ ) and astrocytes (Fig. $2 \mathrm{H}$ ), showing that PDTC treatment reduced the increase in nuclear p65 protein by inflammatory stimuli. However, inflammatory stimuli did not increase nuclear p65 in either the neuronal cell line (N2A) or in the primary neuronal culture (Fig. 2I). These findings suggest that Gnpat expression is reduced by inflammatory 


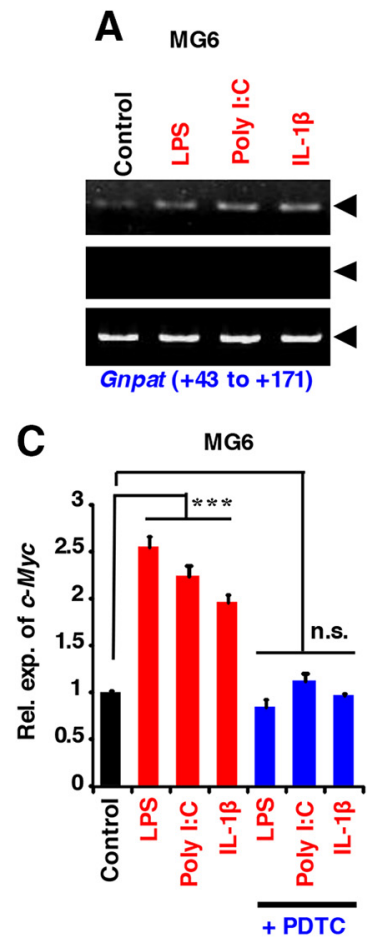

$\mathbf{E}$

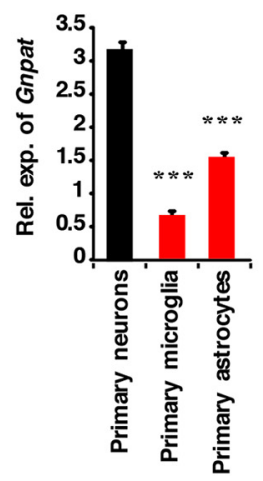

A1

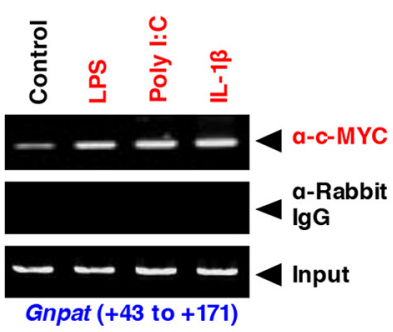

B MG6

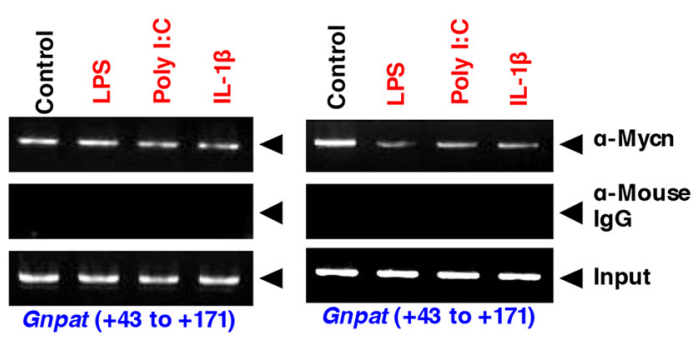

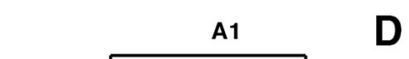

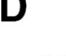

MG6

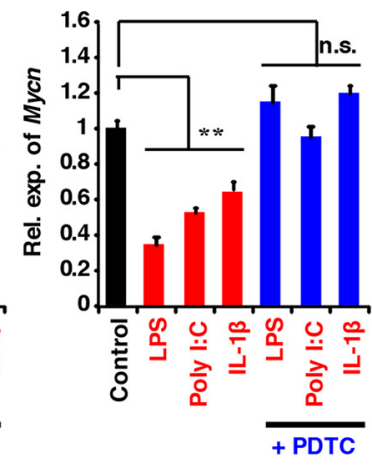

G

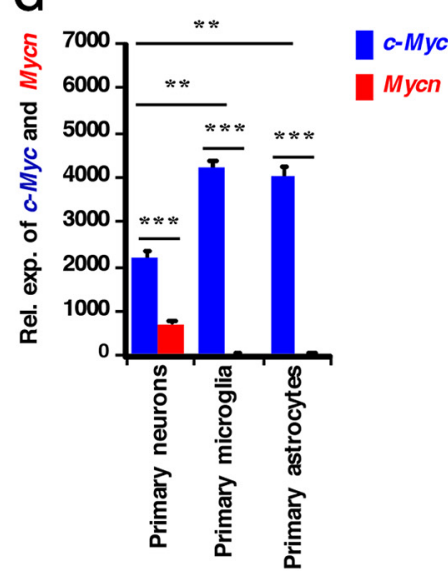

A1

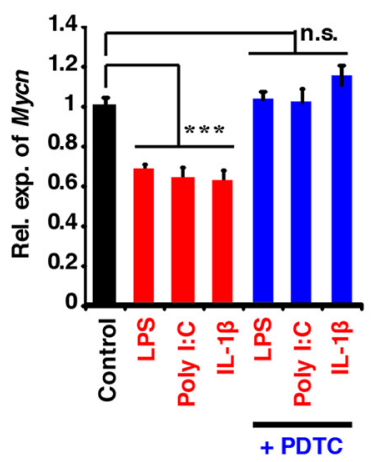

$\mathbf{F}$
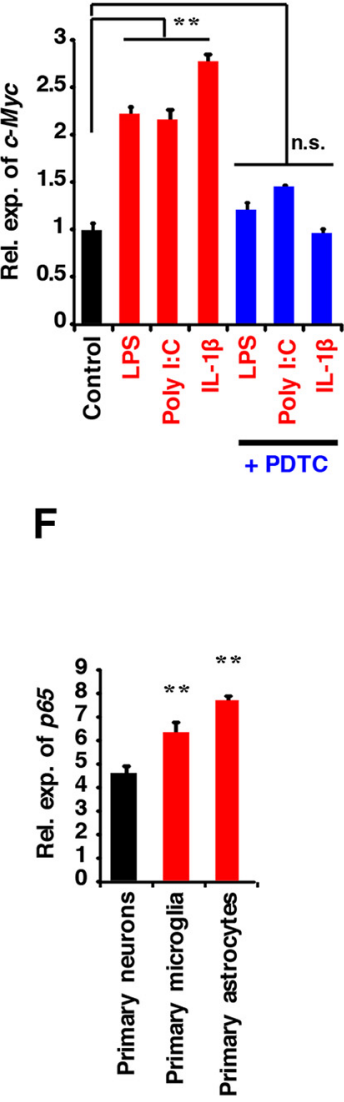

Figure 5. Differential regulation of c-Myc and Mycn by inflammatory stimuli. $\boldsymbol{A}, \boldsymbol{B}$, ChIP data showing increased c-MYC retreatment $(\boldsymbol{A})$ and decreased Mycn recruitment $(\boldsymbol{B})$ onto the Gnpat promoter in the MG6 (left in $\boldsymbol{A}$ and $\boldsymbol{B}$ ) and A1 cells (right) by similar treatments with LPS, Poly I:C, and IL-1 $\beta$ as in Figure 1. C, $\boldsymbol{D}$, Inflammatory stimuli increased $(-M y c(\boldsymbol{C})$ and decreased Mycn (D) expression in MG6 (left) and A1 (right) cells, which were attenuated by the pretreatment with an NF- $\kappa$ B inhibitor, PDTC. $E-G$, Real-time PCR data showing the endogenous expression of GNPAT $(\boldsymbol{E}), p 65(\boldsymbol{F})$, and $\mathrm{c}-$ Myc and Mycn (G) in mouse primary cultured cells. ${ }^{* *} p<0.01 ;{ }^{* * *} p<0.001(n=5)$.

signals both in glial cell lines and primary cultured glia, but not neuronal cells, through activation of the NF- $\kappa$ B pathway.

\section{$\mathrm{NF}-\kappa \mathrm{B}$-mediated recruitment of $\mathrm{c}-\mathrm{Myc}$ onto the promoter region downregulates Gnpat expression}

To identify the possible transcription factors regulating Gnpat expression under the NF- $\kappa \mathrm{B}$ pathway, we cloned the Gnpat promoter regions and identified the maximum promoter activity in glial and neuronal cells from the core promoter $(-150$ to +226$)$ of the first exon (Fig. 3A). This core promoter activity (Fig. 3B) was significantly reduced in the glial cells after exposure to LPS, Poly I:C, and IL- $1 \beta$, but not in neuronal cells (Fig. $3 C-E$ ). The reason that neuronal cells did not respond to these proinflammatory stimuli might have been the low expression of Toll-like receptor 4 (Tlr4), Tlr3, and IL-1R1, receptors for LPS, Poly I:C, and IL- $1 \beta$, respectively (Fig. $3 F-H$ ). Although there was a significant amount of IL-1R1 in the primary neurons, they did not respond to IL- $1 \beta$ to reduce Gnpat expression (Fig. $1 G$ ). This could be explained by the evidence that IL- $1 \beta$ failed to activate NF- $\kappa$ B in primary neurons (Fig. 2I, bottom), which is consistent with other reports (Nadjar et al., 2003; Srinivasan et al., 2004; Allan et al., 2005).

The core Gnpat promoter sequence analysis revealed two possible Myc protein-binding sites within the $5^{\prime}$ - untranslated region (Fig. 4A). ChIP assays showed that both c-Myc and Mycn were recruited onto these sites in the glial and neuronal cells (Fig. $4 B, C)$. Specificity of the antibodies (c-Myc and Mycn) used for the ChIP assays were confirmed by immunoprecipitation assays (Fig. $4 D, E$ ). Appropriate positive and negative control experiments were performed to optimize the ChIP assays (data not shown). We also examined the effects of MYC and NF- $\kappa$ B proteins on Gnpat promoter activity. The Gnpat promoter for lu- 

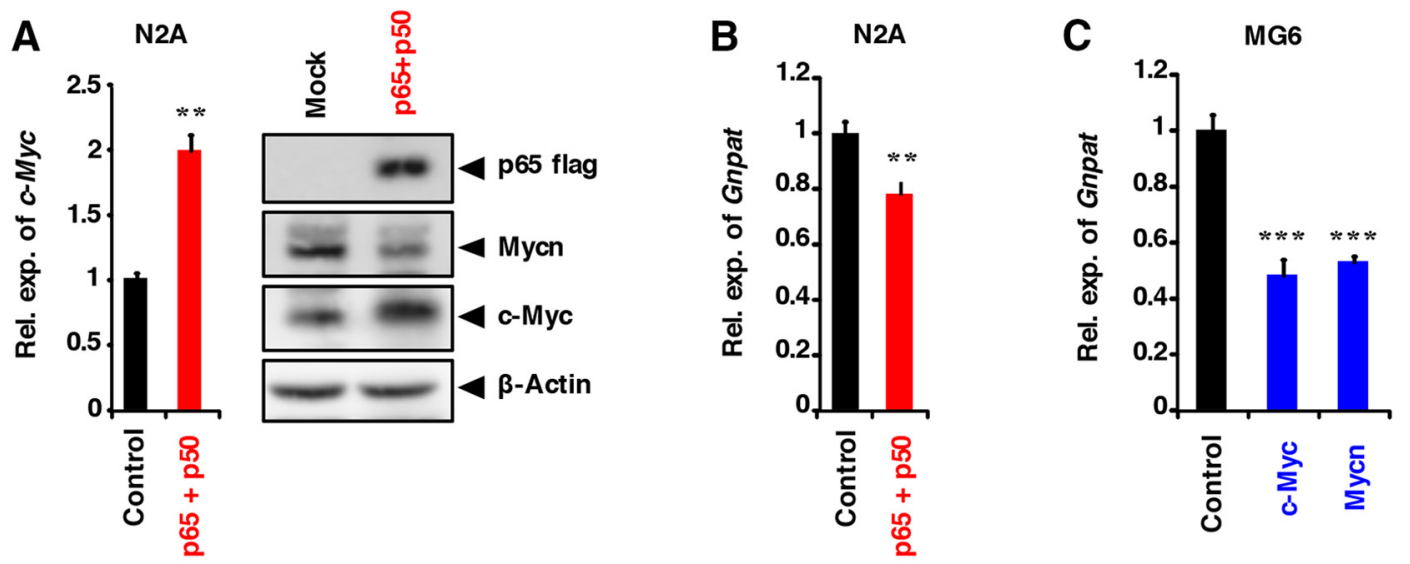

D N2A
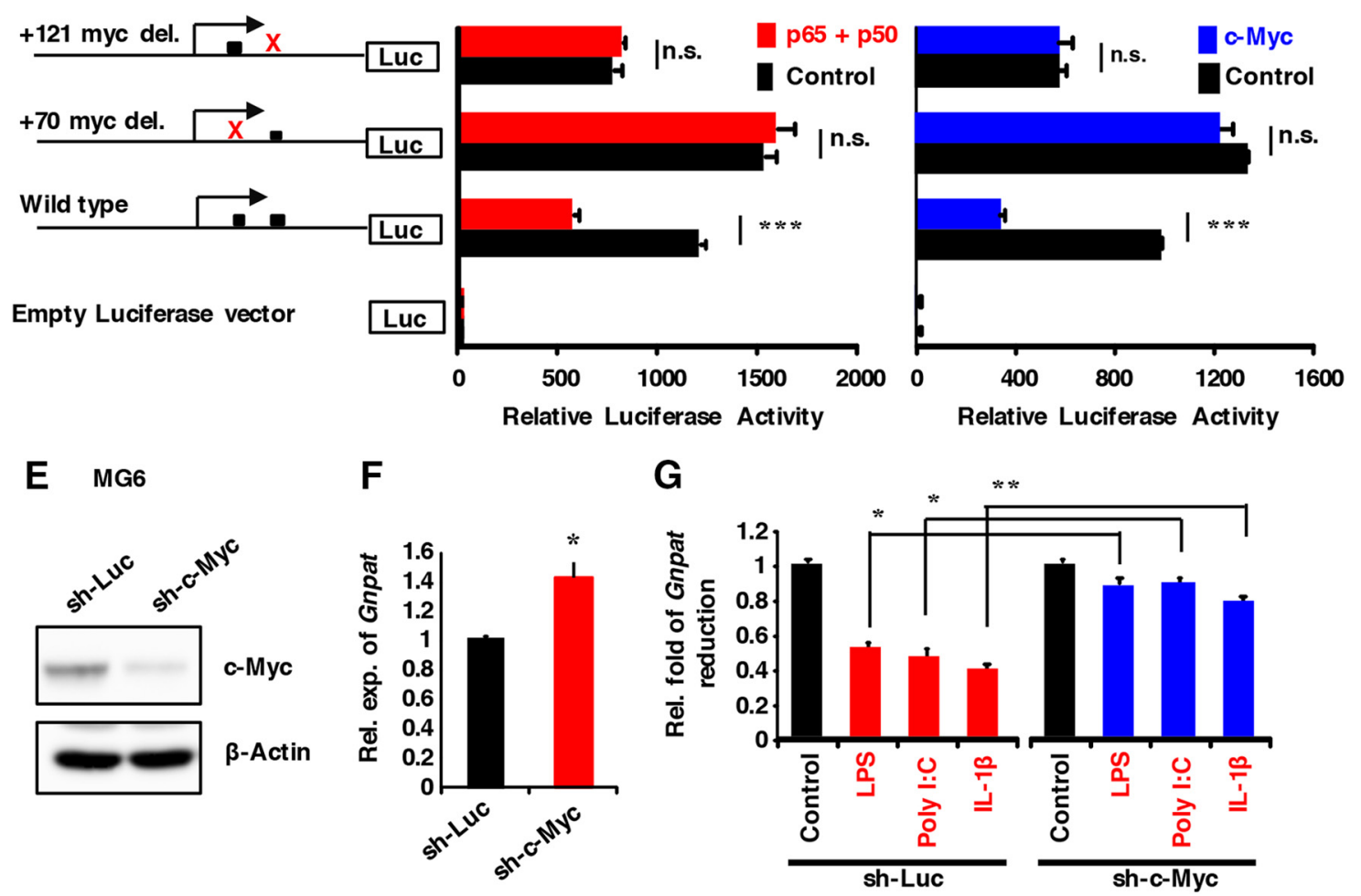

Figure 6. Suppression of Gnpat expression by NF- $\kappa$ B-induced c-Myc. A, Transfection of p 65 - and p50-expressing plasmids $\left(1 \mu\right.$ g each) in N2A cells $\left(1 \times 10^{5}\right.$ cells/well of 6 -well plate) for $48 \mathrm{~h}$ increased c-Myc mRNA (left) and protein (right) expression. $\boldsymbol{B}$, In the same experimental condition, p65 and p50 overexpression reduced Gnpat expression. C, MG6 cells $\left(1 \times 10^{5}\right.$ cells/well of 6 well platees) infected with c-Myc- and Mycn-expressing lentiviruses for $48 \mathrm{~h}$ showing the reduction of Gnpat expression compared with control lentivirus infection. $\boldsymbol{D}$, Luciferase assays in N2A cells showing that the reduction of Gnpat promoter activity by NF- $\kappa$ B (p65 plus p50) (middle panel, third row) and c-Myc (right panel) was canceled by the deletion of Myc-binding sequences from the Gnpat promoter (first and second rows). The data represent six independent experiments. ${ }^{* *} p<0.01{ }^{* * *} p<0.001$. E, Western blot data showing the reduction of c-Myc protein expression in MG6 cells infected with the c-Myc sh-RNA-delivering lentivirus for $48 \mathrm{~h} . F$, Gnpat mRNA expression was increased in the c-Myc knockdown cells. G, Reduction of Gnpat expression induced by $6 \mathrm{~h}$ treatments with LPS $(10 \mu \mathrm{g} / \mathrm{ml})$, Poly l:C $(10 \mu \mathrm{g} / \mathrm{ml})$, and IL-1 $\beta(20 \mathrm{ng} / \mathrm{ml})$ was blocked by c-Myc knockdown in MG6 cells. ${ }^{*} p<0.05 ;{ }^{* *} p<0.01(n=4)$.

ciferase reporter assay revealed that the promoter activity was significantly decreased by overexpression of p65/p50 proteins (Fig. 4F) and c-Myc or Mycn (Fig. 4G) in the N2A cells. N2A cells were used in this experiment because these cells showed a higher transfection efficiency than glial cells.

Interestingly, treatment with LPS, Poly I:C, and IL- $1 \beta$ increased the recruitment of $\mathrm{c}-\mathrm{MYC}$ onto the promoter region of Gnpat $(+43$ to +171$)$ in the microglia (Fig. 5A, left) and astrocytes (Fig. 5A, right) but reduced Mycn recruitment in these cells (Fig. 5B). This can be explained by the evidence that all of these stimuli increase $c-M y c$ expression (Fig. $5 C$ ) but reduce Mycn (Fig. 5D) in glial cells. Most notably, an NF- $\kappa \mathrm{B}$ inhibitor, PDTC, significantly attenuated inflammatory stimuli-induced $c-M y c$ induction and $M y c n$ reduction (Fig. $5 C, D)$, confirming the previous findings that NF- $\kappa \mathrm{B}$ activation increased expression of $c-M Y C$ (La Rosa et al., 1994; Kozlowski and Weimer, 2012). In addition, exposure to inflammatory stimuli did not induce $c-M y c$ in neuronal cells (data not shown), indicating that this induction could be limited to glial cells. Real-time PCR revealed that basal levels of GNPAT mRNA in primary glial cells were less than those in the primary neurons (Fig. $5 E$ ), possibly due to the higher expres- 
A

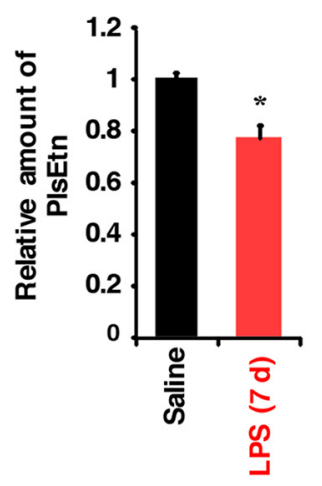

B

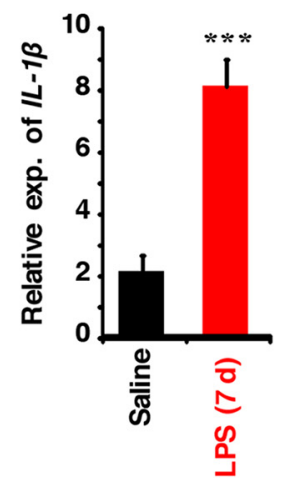

C

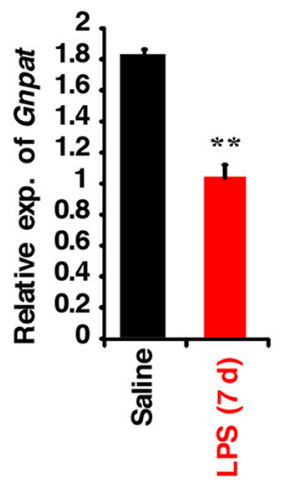

D
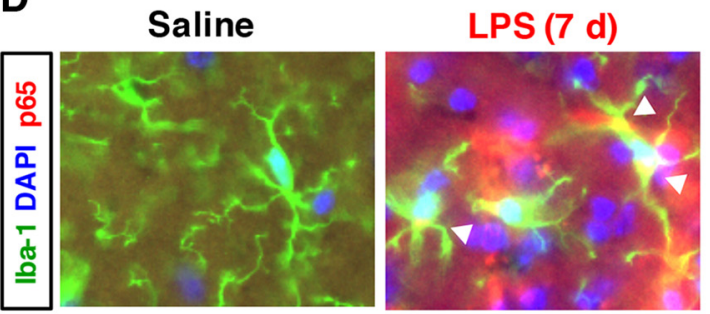

E

$\square$ Saline

LPS (7 d)
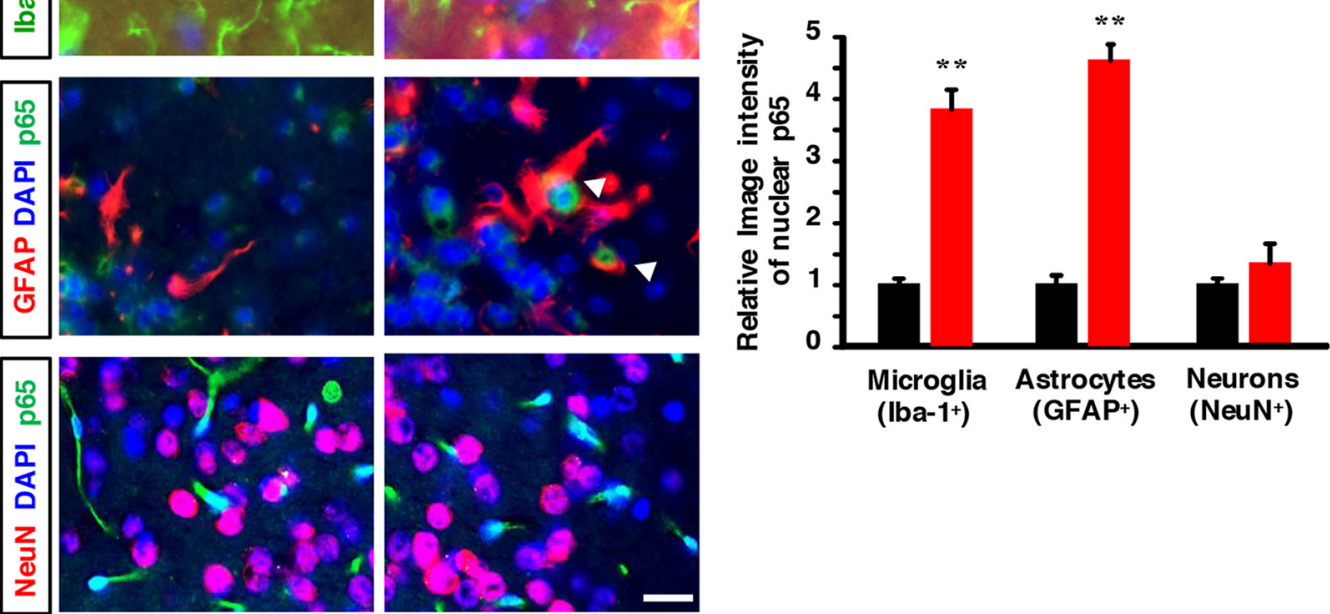

(lba-1+)

(GFAP+)

( $\mathrm{NeuN}^{+}$)

Figure 7. LPS-induced suppression of Gnpat and nuclear localization of p65. $\boldsymbol{A}, \boldsymbol{B}$, Total PIsEtn content was reduced $(\boldsymbol{A})$ and expression of $/ L-1 \beta \mathrm{mRNA}$ was increased $(\boldsymbol{B})$ in the hippocampus of mice injected with LPS (250 $\mathrm{gg} / \mathrm{kg} / \mathrm{d}$, i.p., for 7 d). C, LPS injection reduced expression of Gnpat in the hippocampus. $\boldsymbol{D}$, Increase in nuclear localization of p65 (arrowheads) in the cortical Iba- ${ }^{+}$ microglia (top) and GFAP ${ }^{+}$astrocytes (middle), but not in NeuN ${ }^{+}$-neuronal cells (bottom) by LPS injections. E, Quantification of the nuclear p65 signals showing the significant increase in nuclear localization only in the glial cells of mouse cortex. The data represent 5 mice in each group and 10 slices from a single mouse. Scale bar, $20 \mu \mathrm{m} .{ }^{*} p<0.05 ;{ }^{* *} p<0.01 ;{ }^{* *} p<0.001$.

sion of $p 65$ (Fig. $5 F$ ) and $c-M y c$ in the primary glial cells compared with primary neurons (Fig. 5G).

Consistent with the promoter activity assay, the overexpression of p65/p50 increased $c-M y c$ mRNA (Fig. $6 A$, left) and protein (Fig. $6 A$, right) levels and reduced Gnpat expression in N2A cells (Fig. 6B). These findings indicate that, although inflammatory stimuli failed to reduce Gnpat and activate NF- $\kappa$ B in neuronal cells, alternative activation of NF- $\kappa$ B and MYC overexpression can lead to the reduction of Gnpat in the neuronal cells. Furthermore, overexpression of c-Myc and Mycn reduced Gnpat expression in microglial cells (Fig. $6 C$ ), astrocytes, and neuronal cells (data not shown), suggesting that increased expression of either NF- $\kappa$ B or Myc proteins could reduce the Gnpat transcription in any of these cells. To confirm that the reduction of Gnpat expression was due to the Myc proteins, we deleted one of the two Myc-binding consensus sequences (red " $x$ " in Fig. $6 D$, left) from the promoter and found that neither p65/p50 nor c-Myc overexpression reduced the mutated Gnpat promoter activity (Fig. $6 D$, middle and right). Furthermore, knockdown of $c-M y c$ by lentiviruses encoding the short hairpin RNA against $c-M y c$ in micro- glial cells (Fig. 6E) significantly increased the basal Gnpat expression (Fig. $6 F$ ) and attenuated Gnpat downregulation by inflammatory stimuli (Fig. 6G).

Pls and Gnpat expression are reduced in inflammatory/stress model mice

We then sought to clarify the role of Pls using in vivo model of neuroinflammation. When mice were intraperitoneally injected with LPS over a period of $7 \mathrm{~d}$, the level of PlsEtn in the hippocampus was significantly reduced and the expression of IL- $1 \beta$ mRNA increased (Fig. $7 A, B$ ), as we reported previously (Ifuku et al., 2012). LPS injections significantly reduced hippocampal Gnpat expression (Fig. $7 C$ ) and increased nuclear localization of p65 in the Iba- $1^{+}$microglia and $\mathrm{GFAP}^{+}$-astrocytes, but not $\mathrm{NeuN}^{+}$neurons (Fig. $7 D, E$ ). In addition to the LPS model, aged mice (16 months old) and mice subjected to CRS also showed reduction of Gnpat expression and PlsEtn content with the increase in $I L-1 \beta$ expression in the hippocampus (Fig. $8 A, B$ ). More consistently, we also noticed that in both the aged and CRS groups of mice, p 65 
A

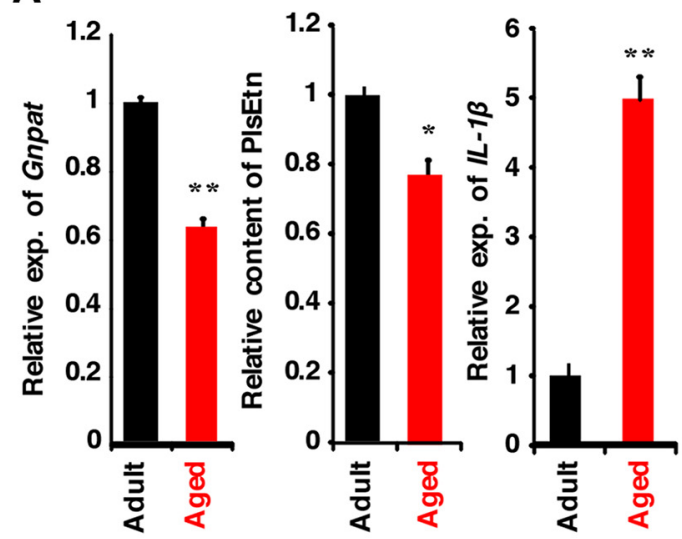

C
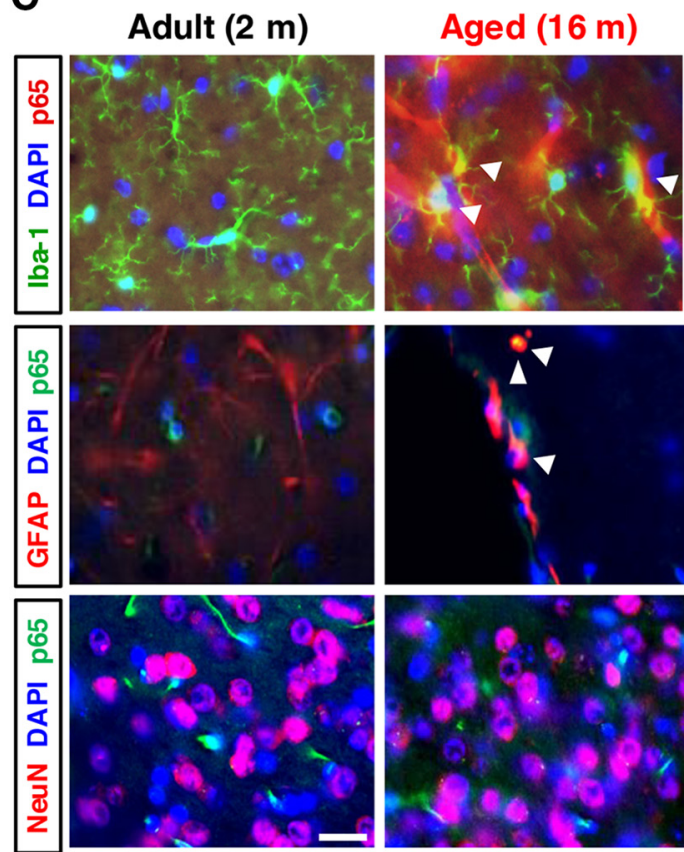

D

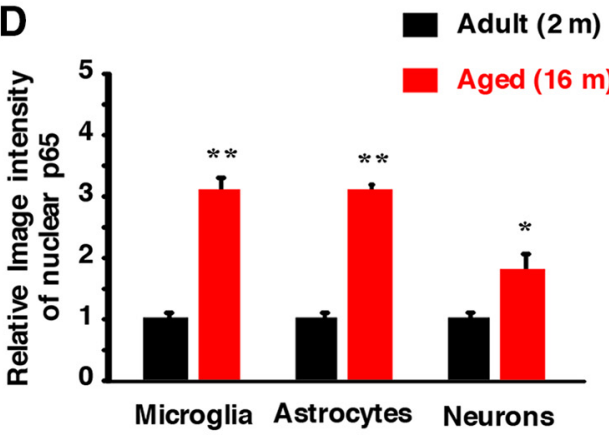

B

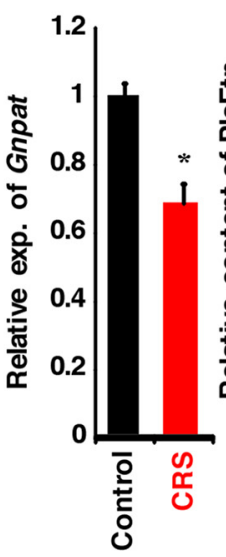

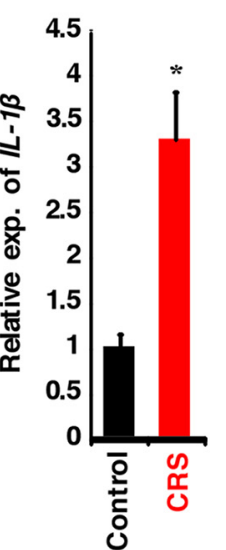

CRS
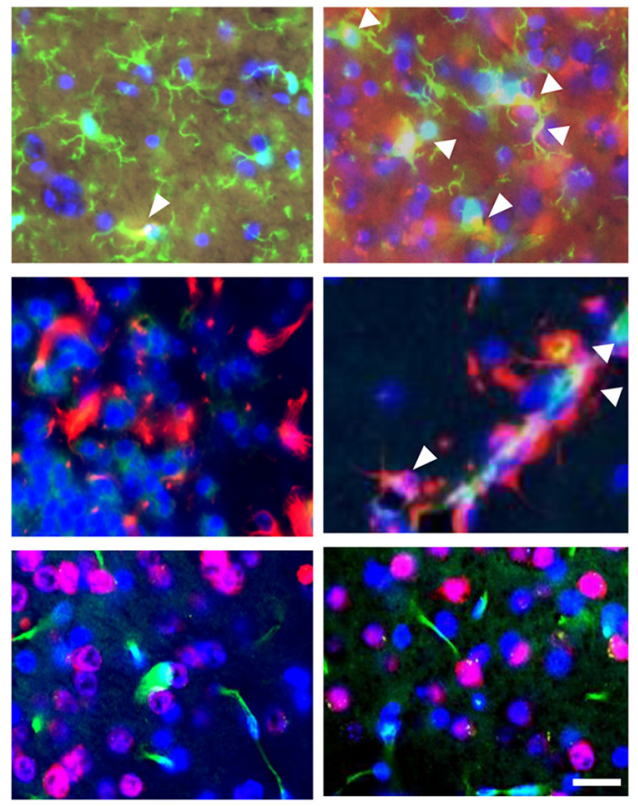

E

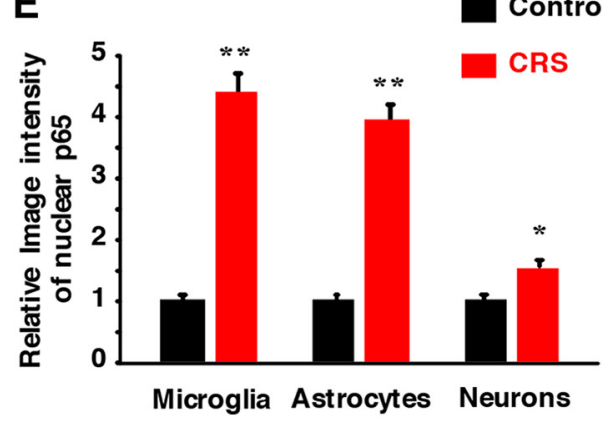

Figure 8. Reduction of Gnpat and PIsEtn in aged mice and mice subjected to CRS. $A$, mRNA expression for Gnpat and relative PlsEtn content were decreased, whereas IL-1 $\beta$ expression was increased, in the hippocampal tissues of aged mice $(n=6) . \boldsymbol{B}$, Similar changes in Gnpat, PIsEtn content, and IL-1 $\beta$ in the hippocampus of mice subjected to CRS were observed. C, Immunohistochemical data showing increases in nuclear localization of p65 (arrowheads) in Iba- ${ }^{+}$microglia (top) and GFAP ${ }^{+}$astrocytes in the cortex of aged mice and CRS mice compared with the respective control groups. Scale bar, $20 \mu \mathrm{m}$. D, E, Quantification of data in ( showing marked increases in nuclear p65 in glial cells and small but significant increases in neurons of aged (D) and (RS (E) mice. ${ }^{* *} p<0.01(n=5)$.

nuclear localization was prominent in glial cells (Fig. 8C-E). However, in contrast to LPS injection (Fig. 7E), aged and CRS mice showed small but significant increases in nuclear p65 immunoreactivity in neuronal cells (Fig. $8 D, E$ ).
c-Myc expression is increased in neuroinflammation models To address the question of whether the increased c-Myc recruitment in cultured cells can be also found in brain tissues of LPS, aged, and CRS mice, we examined hippocampal tissues 
A

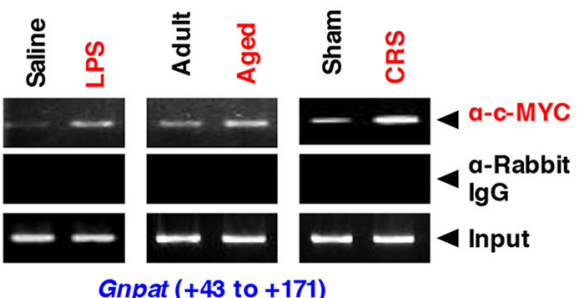

C
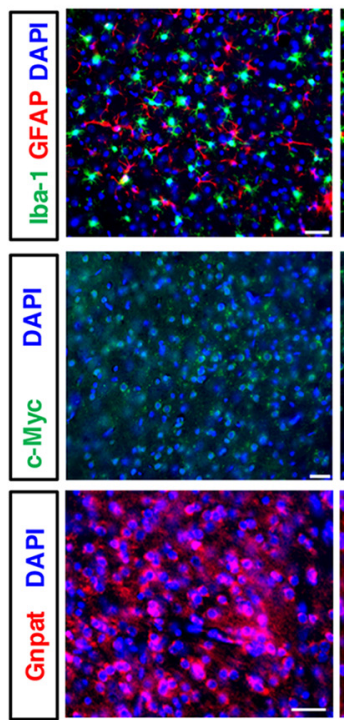

F
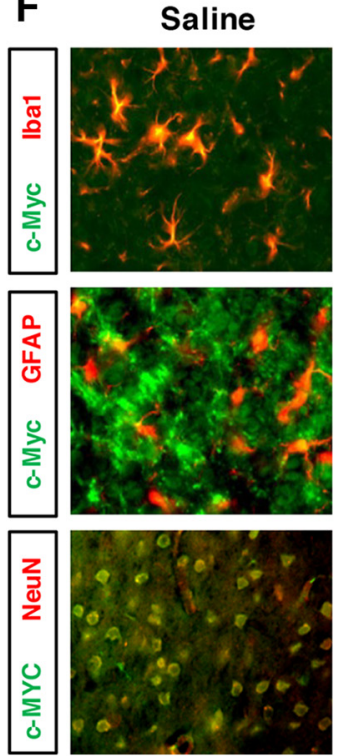
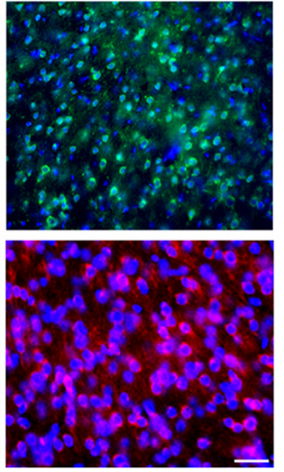

LPS

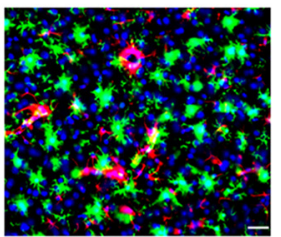

LPS
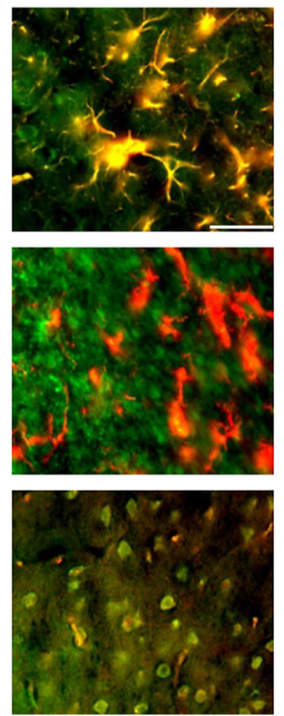

B
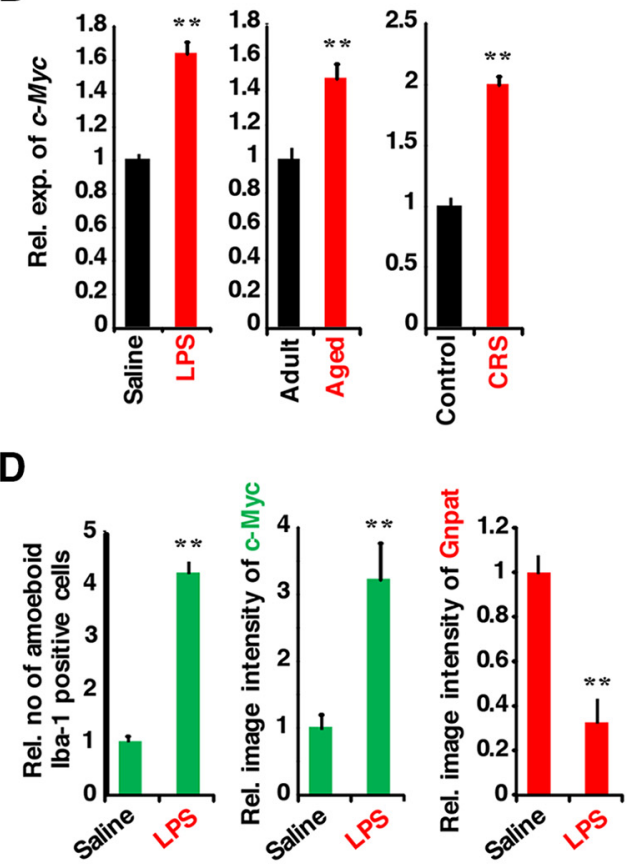

E
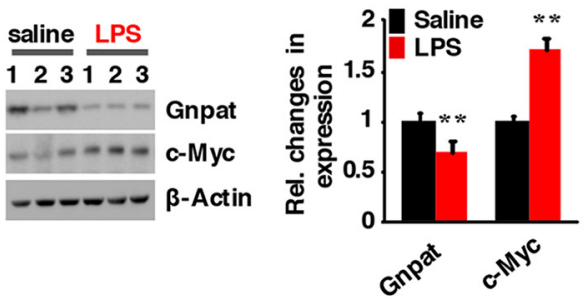

G

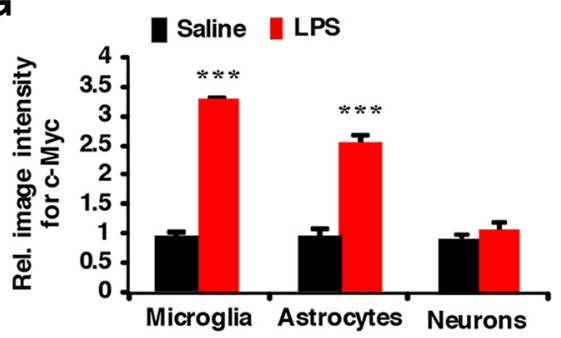

H

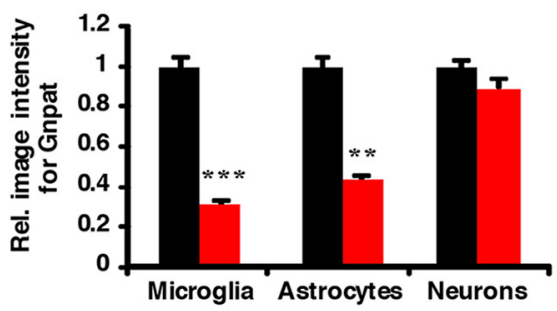

Figure 9. Increases in c-Myc expression in the mouse neuroinflammation model. $\boldsymbol{A}$, ChIP assays showing increased recruitment of c-Myc onto the Gnpat promoter in the hippocampal tissues from mice injected with LPS ( $250 \mu \mathrm{g} / \mathrm{kg} / \mathrm{d}$, i.p., for $7 \mathrm{~d}$ ), aged mice (16 months), and mice subjected to CRS compared with the saline-injected, adult ( 2 months), and sham groups, respectively. $\boldsymbol{B}$, $(-M y c$ expression was increased in the cortex of LPS, aged, and CRS mice. C, Immunohistochemical data for Iba-1, GFAP, c-Myc, and Gnpat expression in the cortex of LPS-injected mice and the saline group. Scale bar, $50 \mu \mathrm{m}$. D, Quantification of data in C showing increase in amoeboid lba- ${ }^{+}$microglial cells and c-Myc and Gnpat expressions in LPS-injected mice ( $n=5$ ). $\boldsymbol{E}$, Protein expression of Gnpat, c-Myc, and $\beta$-actin (loading control) in the cortical tissue of three representative mice from the LPS and saline groups. Right panel shows the relative changes in the protein expression. $\boldsymbol{F}$, Immunohistochemical data showing coexpression of c-Myc with the NeuN, Iba-1, and GFAP in the LPS and saline groups. Scale bar, $50 \mu$ m. $\mathbf{G}$, Quantification of data in $\boldsymbol{F}$ showing increases in c-Myc protein in glial cells but not in neurons. $\boldsymbol{H}$, Quantification data of Gnpat costained with the Iba-1, GFAP, and NeuN. The image data for this graph are available upon request. All of the image quantification data were derived from 5 mice in each group. More than 7 slices of each mouse brain were examined. ${ }^{* *} p<0.01 ;{ }^{* * *} p<0.001$. 
A

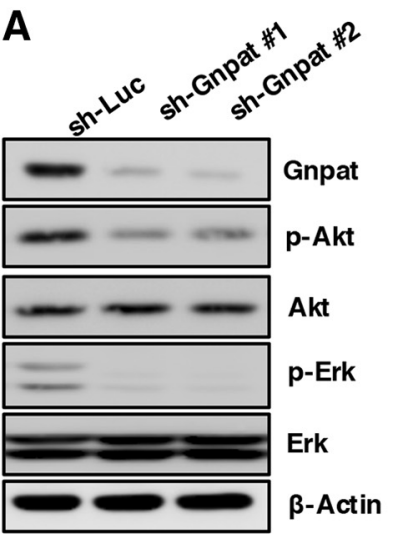

D

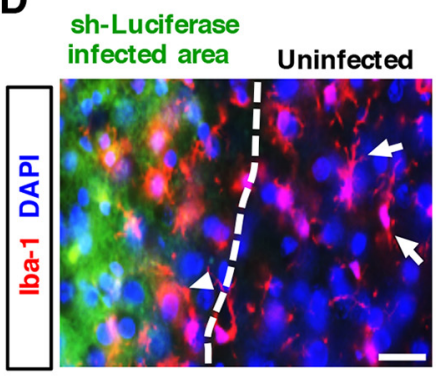

B

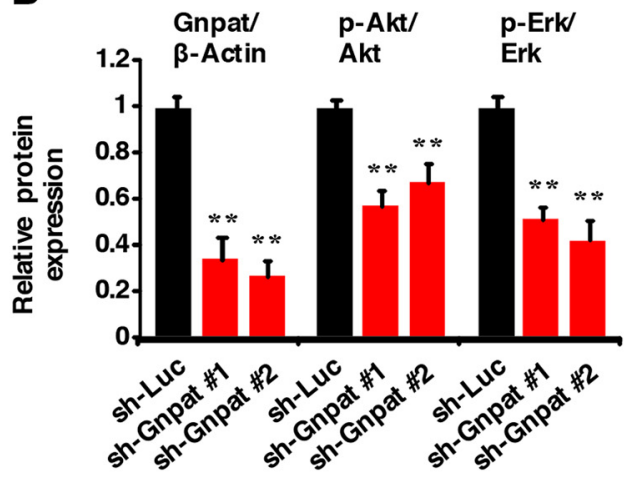

E

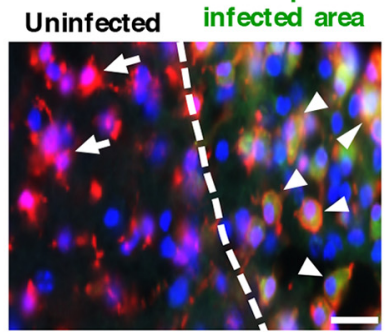

C

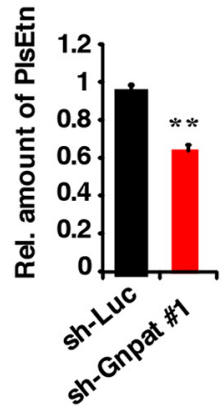

F

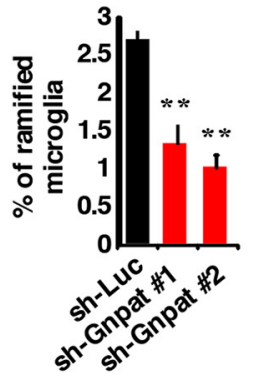

G

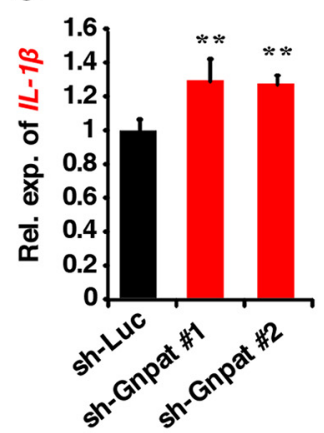

K

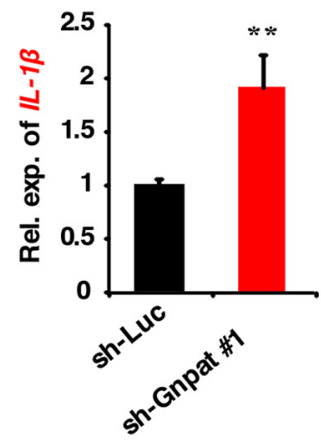

H

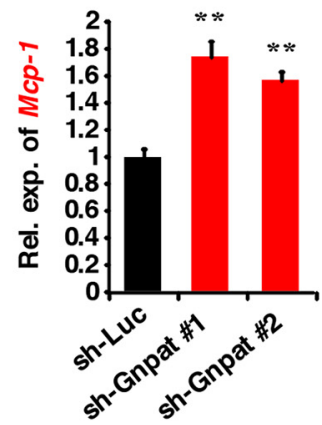

L

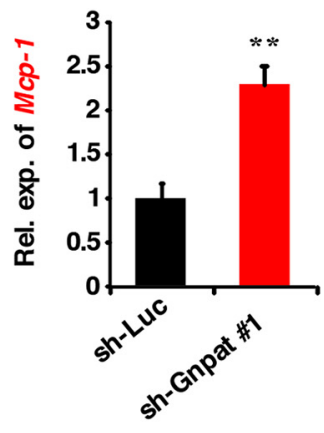

I

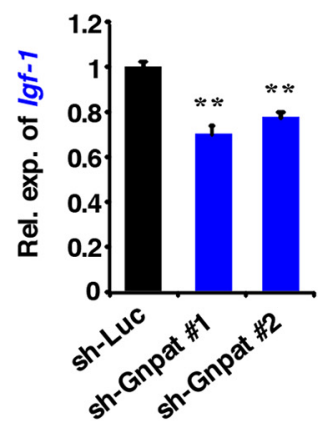

M

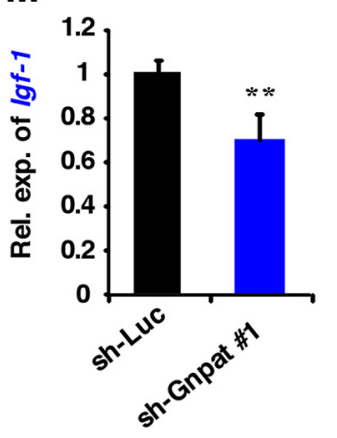

$\mathbf{J}$

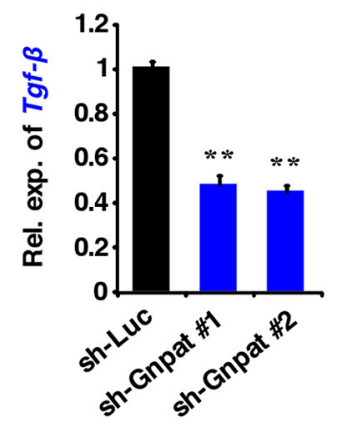

$\mathbf{N}$

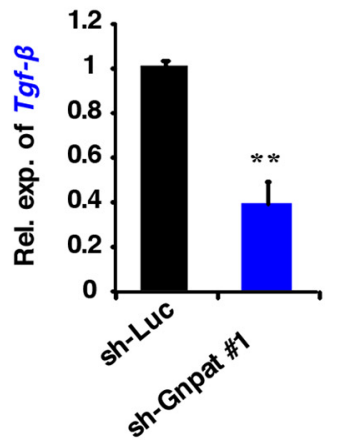

Figure 10. Glial activation induced by knockdown of Gnpat. $\boldsymbol{A}, \boldsymbol{B}$, Western blot data $(\boldsymbol{A})$ and summary $(\boldsymbol{B})$ of infected cortical tissues showing a decrease in the Gnpat, $\mathrm{p}$-Akt, and p-Erk proteins by injection of lentiviruses encoding sh-RNA against Gnpat (sh-Gnpat \#1 and \#2) compared with the control sh-Luc-infected area. $C$, LC-MS data showing the reduction of total PIsEtn in the infected area of the knockdown mice $(n=4)$. $D$, Two weeks after intracranial injection of $0.5 \mu$ l of sh-Gnpat \#1 $\left(5 \times 10^{5}\right.$ transduction units) in the cortex, immunohistochemistry was performed with Iba- 1 antibody (red). Amoeboid (arrowhead) and ramified (arrow) lba-1-positive microglia were counted in the GFP-positive infected area (green) and uninfected areas from $>20$ brain slices from 5 mice of each group. Scale bar, $20 \mu \mathrm{m} . \boldsymbol{E}, \boldsymbol{F}$, In the sh-Gnpat-infected area, the number of amoeboid microglia increased $(\boldsymbol{E})$, whereas the number of ramified microglia decreased $(\boldsymbol{F})$. $\boldsymbol{G}-\boldsymbol{J}$, In the same experimental condition of $\boldsymbol{D}$, real-time PCR was performed using the RNA extracted from the lentivirus injection sites to determine the expression of mRNAs for $I L-1 \beta(\boldsymbol{G}), M c p$ - $1(\boldsymbol{H})$, I $\mathbf{g} f-1(\boldsymbol{I})$, and Tgf- $\beta(\boldsymbol{J})$. $\boldsymbol{K}-\boldsymbol{N}$, The microglial (MG6) cells were infected with sh-Gnpat for $72 \mathrm{~h}$ followed by real-time PCR to determine the expression of mRNAs for $/ \boldsymbol{L}-1 \beta(\boldsymbol{K}), M c p-1(\boldsymbol{L})$, Igf- $1(\boldsymbol{M})$, and $T g f-\beta(\boldsymbol{N})$. ${ }^{*} p<0.05 ;{ }^{* *} p<0.01 ;{ }^{* * *} p<0.001(n=5)$. 
A

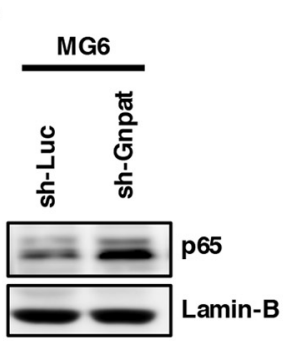

C
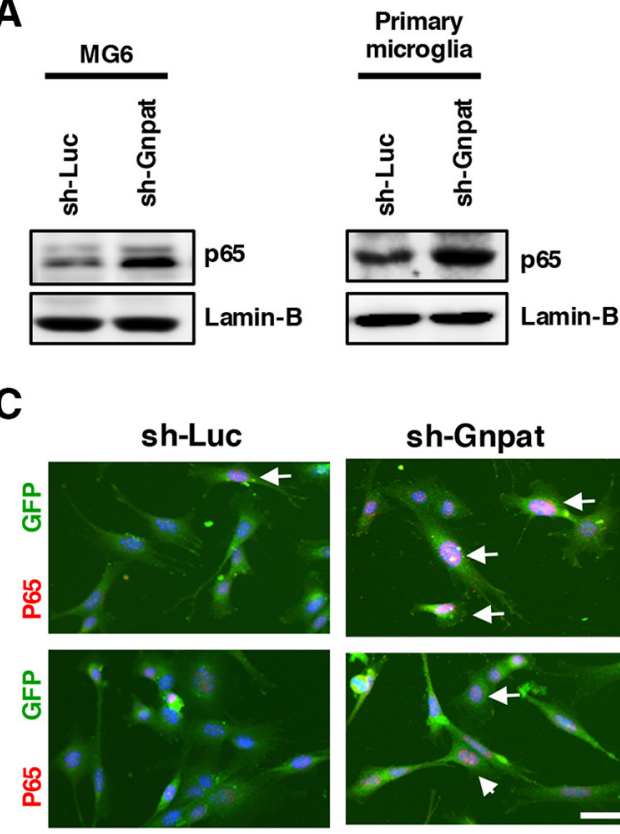

B

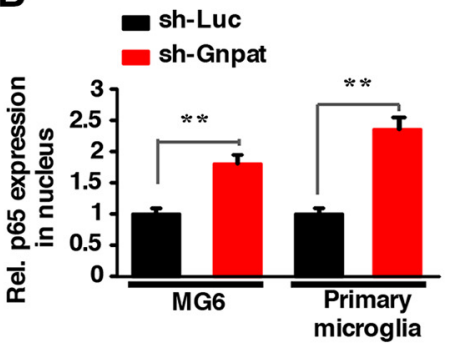

D
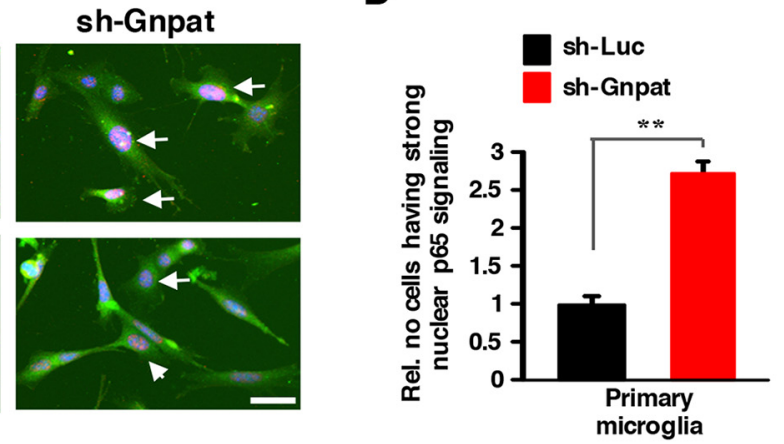

E

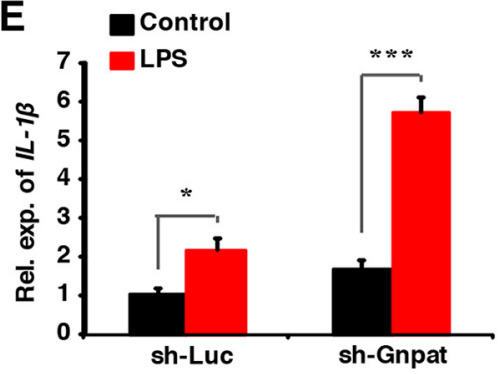

$\mathbf{F}$

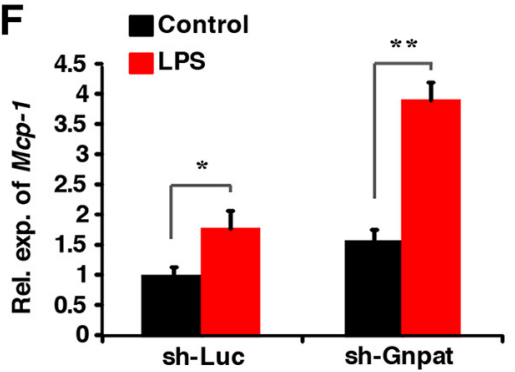

Figure 11. Nuclear localization of p65 is increased by the knockdown of Gnpat. $\boldsymbol{A}, \boldsymbol{B}$, Western blot data $(\boldsymbol{A})$ and summary $(\boldsymbol{B})$ of lentivirus-infected MG6 cells and the primary microglial cells tissues showing a significant increase in nuclear p65 protein expression by sh-Gnpat compared with control sh-Luc. The nuclear fractions were collected after $72 \mathrm{~h}$ of the lentivirus infections. The data represent 5 independent experiments. ${ }^{* *} p<0.01(n=5)$. $\boldsymbol{C}, \boldsymbol{D}$, Merged images of immunocytochemistry $(\boldsymbol{C})$ and summary (D) showing a significant increase in nuclear p65 in primary microglial cells by sh-Gnpat. Cells having strong nuclear p65 staining were counted from a total of $200 \mathrm{GFP}$-positive cells randomly chosen from 5 observation areas of each experimental slide. ${ }^{* *} p<$ $0.01(n=5) . \boldsymbol{E}, \boldsymbol{F}$, mRNA expression of $I L-1 \beta(\boldsymbol{E})$ and $M c p-1(\boldsymbol{F})$ was increased more significantly among the sh-Gnpat-infected primary microglial cells by LPS treatment ( $1 \mu \mathrm{g} / \mathrm{ml}$ for $24 \mathrm{~h}$ ) compared with the control sh-Luc group. ${ }^{* *} p<0.01(n=5)$.

and observed an increased recruitment onto the Gnpat promoter region using the ChIP assay (Fig. 9A). In the same mice, expression of $c-M y c$ was also increased in the cortex (Fig. 9B). Because glial cells expressed only small amount of $M y c n$ compared with $c-M y c$ (Fig. $5 G$ ), it was likely that the reduction of Gnpat expression was caused mainly by c-Myc induction during inflammatory stimuli. LPS injection induced activation of microglia and astrocytes, as indicated by amoeboid/hypertrophic changes (Fig. 9C, top, $D$, left), with an increase in c-Myc (Fig. 9C,D, middle) and a decrease in Gnpat (Fig. 9C, bottom, $D$, right) in the cortex. Western blot analysis of the tissues also showed an increase in c-MYC and a decrease in Gnpat proteins (Fig. 9E). The increases in c-Myc and the decreases in Gnpat were observed in the activated $\mathrm{Iba}_{-1}{ }^{+}$microglia and GFAP ${ }^{+}$ astrocytes, but not in neurons (Fig. $9 F-H$ ), which might be consistent with the findings that systemic LPS did not activate $\mathrm{NF}-\kappa \mathrm{B}$ in neuronal cells (Fig. $7 E$ ).

Knockdown of GNPAT induces glial activation in vivo Microglial activation is often described as the increased conversion from ramified (resting) to amoeboid (activated) morphol-

ogy after exposure to proinflammatory cytokines (Kettenmann et al., 2011; Kozlowski and Weimer, 2012). To assess the possible impact of the reduction of Gnpat in glial cells, we performed an intracortical injection of lentiviruses encoding shGnpat (\#1 or \#2). Two weeks after the injection, Western blotting assays showed significant decreases in Gnpat proteins, along with a reduction of $\mathrm{p}$-AKT and p-ERK (Fig. 10A,B). The decreases in p-Akt and p-Erk seem to be consistent with our previous report showing Plsinduced activation of Akt and Erk signaling (Hossain et al., 2013). LC-MS analysis also showed a significant reduction of $\mathrm{Pls}$ content in the infected brain regions (Fig. $10 C)$. Interestingly, a significant increase in activated (amoeboid) microglia was found in the sh-Gnpat-infected brain region, which was further associated with the decrease in resting (ramified) microglia compared with the control shLuciferase infected area (Fig. 10D-F). In support of the morphological changes, we also observed an increase in proinflammatory cytokines ( $I L-1 \beta$ and $M c p-1)$ and a decrease in anti-inflammatory genes (Igf- 1 and $T g f-\beta$ ) expression in the infected brain regions (Fig. 10G-J). Consistent with the in vivo study, knockdown of Gnpat induced by sh-Gnpat \#1 in cultured microglial cells showed enhanced gene expression of $I L-1 \beta$ and $M c p-1$ and decreased expression of $I g f-1$ and Tgf- $\beta$ (Fig. $10 K-N)$.

\section{Knockdown of Gnpat induces glial activation in vitro}

To support the in vivo findings that reduction of Gnpat can lead to the microglial activation in the murine cortex, we knocked down Gnpat in the microglial cell culture and determined NF- $\kappa \mathrm{B}$ activation. Nuclear localization of $\mathrm{p} 65$ is a common marker of NF- $\kappa \mathrm{B}$ activation associated with the microglial activation and neuroinflammation, which was also observed in the AD brain tissue (Chen et al., 2012). Surprisingly, Gnpat knockdown significantly increased the nuclear localization of p65 protein in the microglial cells and also in the primary microglial cultures (Fig. 11A-D). Consistent with the increased proinflammatory gene expression in in vivo brain tissue, we also observed an enhancement of the LPS-induced expression of the $I L-1 \beta$ and $M c p-1$ genes (Fig. $11 E, F$ ).

Expression of GNPAT is also reduced in human cell lines by $\mathrm{NF}-\boldsymbol{\kappa} \mathrm{B}$ and $\mathrm{c}-\mathrm{MYC}$

To determine whether GNPAT reduction by inflammatory signals can also be seen in human cells, we overexpressed p65 and p50 proteins in human SH-SY5Y and Hek293-T cells. Overexpression of NF- $\kappa \mathrm{B}$ proteins reduced the protein and mRNA expression of GNPAT in those cells (Fig. 12 A, B). Consistent with the murine cells, NF- $\kappa \mathrm{B}$ overexpression caused the increase in c-MYC protein expression in SH-SY5Y cells 
A

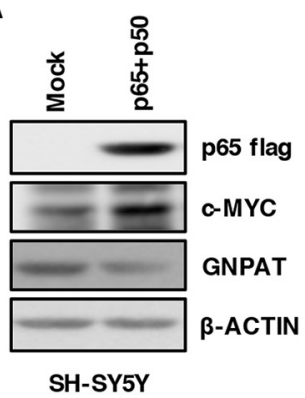

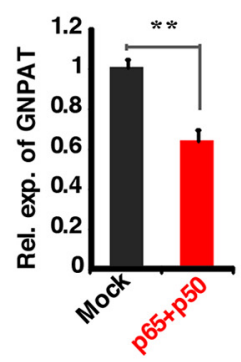

C
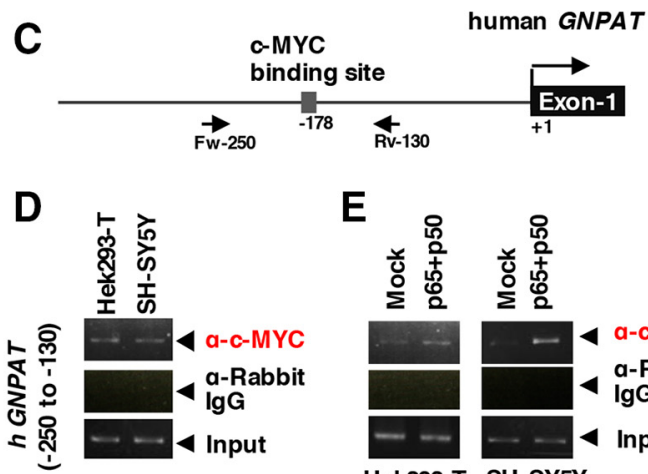

E

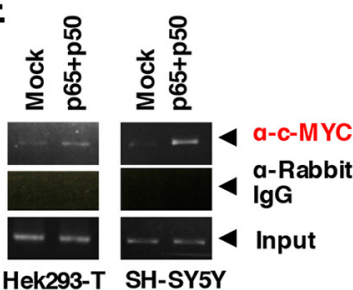

B

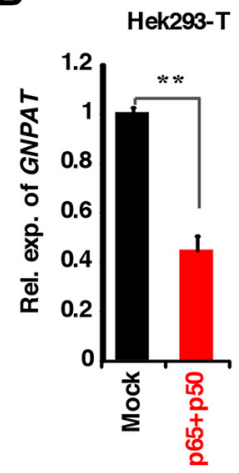

SH-SY5Y

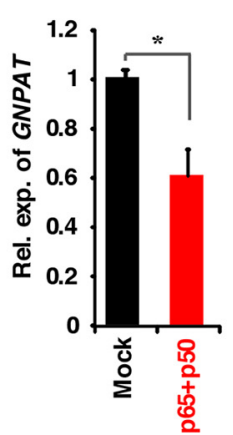

$\mathbf{F}$
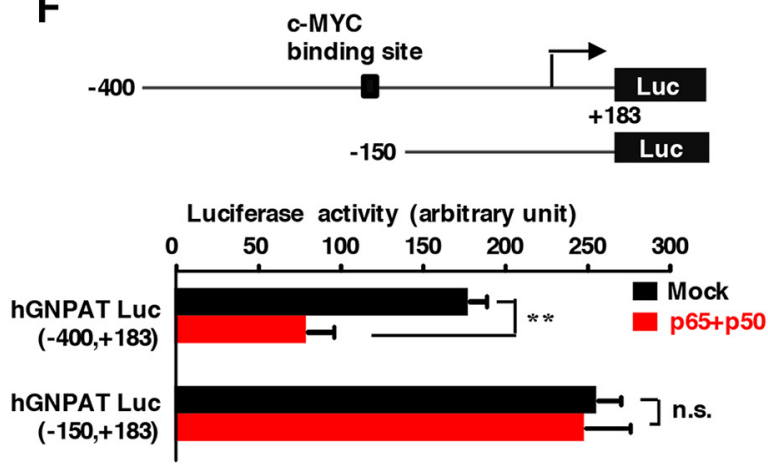

Figure 12. Overexpression of $\mathrm{p} 65$ and p50 reduces the expression of GNPAT in human cell lines. $A$, Western blot data showing an increase in c-MYC and decrease in GNPAT protein expression by the transient transfection of p65 and p50 expressing plasmids in SH-SY5Y cells for $48 \mathrm{~h}$. B, Real-time PCR data performed after $48 \mathrm{~h}$ of overexpression showing the decrease in GNPAT expression by the overexpression of $\mathrm{p} 65$ and $\mathrm{p} 50$ in the cells. C, Position of c-MYC-binding sites and the primer locations for the ChIP assays onto the human GNPAT promoter. The number (+1) indicates the transcription start site located within the first exon. $\boldsymbol{D}, \boldsymbol{E}$, ChIP assays showing the recruitment of c-MYC proteins onto the binding sites of GNPAT promoter in the steady state (D) and after the overexpression of p65 and p50 proteins in the cells for $48 \mathrm{~h}(\boldsymbol{E}) . \boldsymbol{F}$, Schematic representing the cloned human GNPAT promoter regions in the luciferase vector. The short form of the promoter $(-150$ to +183 ) lacks the putative c-MYC-binding site (C). Promoter assays showed that the overexpression of p65 and p50 proteins could not reduce the promoter activity of the human GNPAT promoter lacking the c-MYC binding site $(n=5)$.

(Fig. 12A). We also identified a c-MYC-binding consensus sequences onto the human GNPAT promoter region (Fig. $12 C)$. ChIP analysis showed that c-MYC protein was recruited onto this promoter site of both the human cell lines Hek293-T and SH-SY5Y (Fig. 12D). Overexpression of NF- $\kappa$ B proteins increased the c-MYC protein recruitments onto this promoter site in these cell lines (Fig. 12E), which suggested that this increased recruitment could be associated with the reduction of GNPAT expression that we observed in the murine cells. This was further supported by the finding that the promoter construct lacking this c-MYC-binding site did not respond to the overexpression of NF- $\kappa \mathrm{B}$ proteins in $\mathrm{SH}-\mathrm{SY} 5 \mathrm{Y}$ cells (Fig. $12 F$ ). These data suggest that NF- $\kappa \mathrm{B}$ activation can also reduce the expression of GNPAT in human cells as in murine cells.

\section{$\mathrm{AD}$ mice model and postmortem $\mathrm{AD}$ brain tissues also show an increase in c-Myc and a reduction of Gnpat expression in glial cells}

Finally, we investigated whether the reduction of Pls content was associated with the reduction of Gnpat expression via NF- $\kappa \mathrm{B}$ and $\mathrm{c}-\mathrm{Myc}$ signaling in the $\mathrm{AD}$ brain. It has been shown previously that there was a significant reduction of total Pls in the brain tissue of amyloid precursor protein (APP)-transgenic AD model mice compared with control mice (Han et al., 2001). In the present study, we used a triple-transgenic (3Tg) AD mouse model (Oddo et al., 2003) and found a significant reduction of total PlsEtn in the 18-month-old 3Tg mice compared with control mice of the same age (Fig. 13A). We then determined protein expression in the nuclear fractions of hippocampal and cortex tissues and found an increased amount of nuclear p65 protein in the 3Tg AD model mice brain compared with the control mice (Fig. 13B). Total tissue lysates showed the significant increase in c-Myc and decrease in Gnpat expression in the 3Tg mice hippocampus and cortex tissues (Fig. $13 B-D)(p<0.01)$. We then examined the brain tissue sections by immunohistochemistry and observed a significant increase in c-Myc and a decrease in Gnpat proteins in the Iba-1 positive glial cells of 3Tg mice (Fig. $13 E-H)$. To prove that these $3 \mathrm{Tg}$ mice have a significant amount of $\mathrm{A} \beta$ deposition in the cortex, we performed immunostaining with the specific antibody against $\mathrm{A} \beta$ (Fig. 13I). We also confirmed that there was an increase in $\mathrm{c}-\mathrm{MYC}$ and a decrease in GNPAT proteins in the Iba-1-positive glial cells of human postmortem AD brain tissues compared with that from healthy control subjects (Fig. 13J,K). These data suggest that the similar changes in c-MYC and GNPAT proteins can be observed in the $\mathrm{AD}$ brains of both mice and humans and this may be correlated with the reduction of brain Pls.

\section{Discussion}

It is well known that the human brain contains a limited number of neuronal cells compared with the huge numbers of the glial cells, suggesting that brain glial cells are the major reservoir for brain Pls. Pls contain a saturated fatty acid with a vinyl-ether bond at the $s n-1$ position and the $s n-2$ position is enriched in polyunsaturated fatty acids such as arachidonic acid and docosahexaenoic acid, which are released by Pls-selective phospholipase 


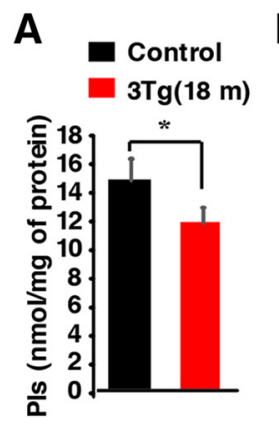

E

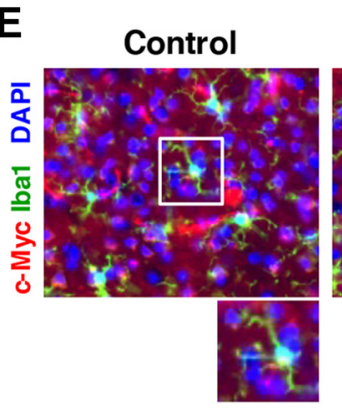

G

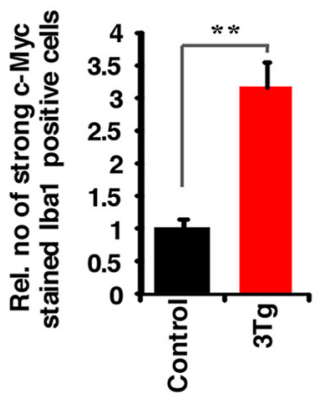

J

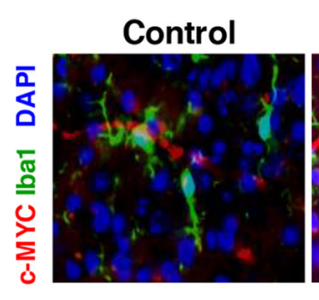

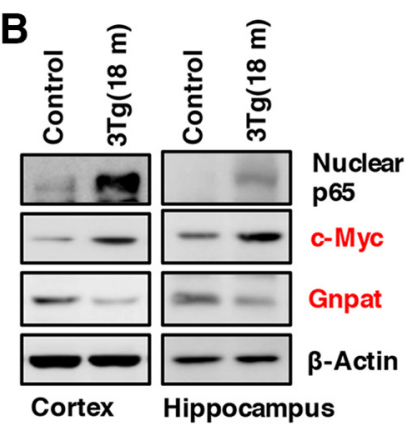

F

$3 \operatorname{Tg}(18 \mathrm{~m})$

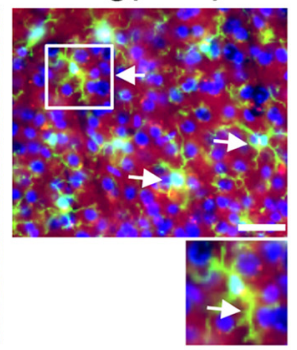

H

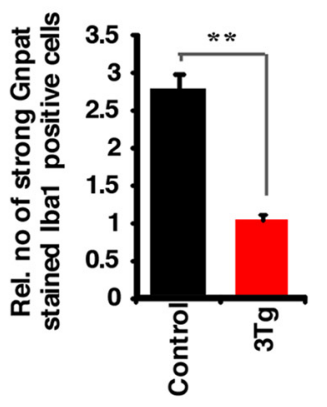

C

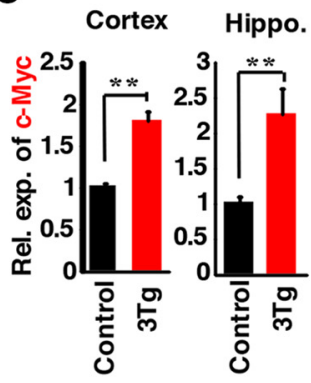

D
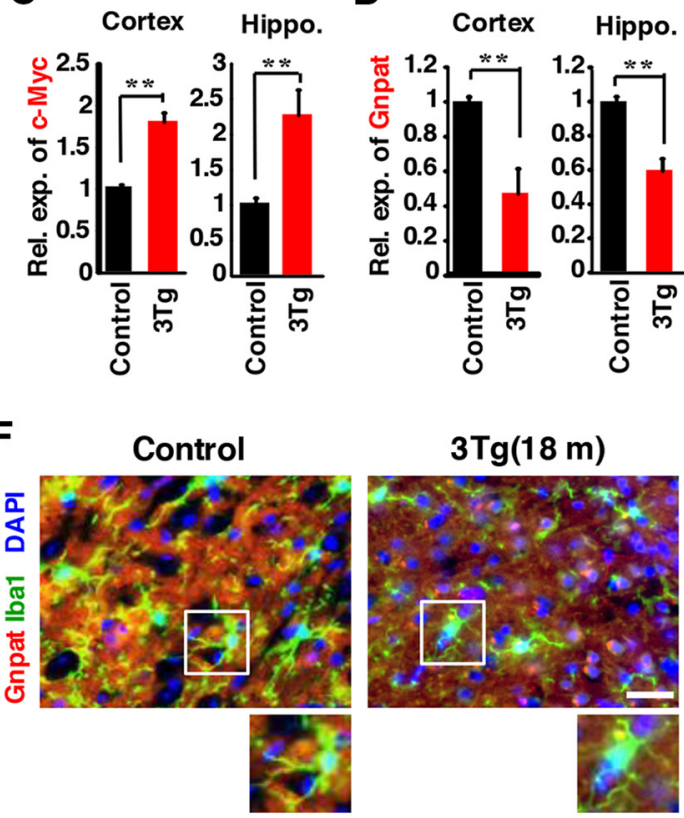

I

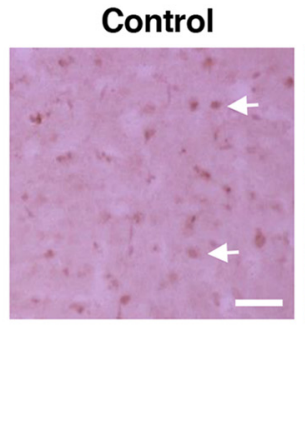

$3 \operatorname{Tg}(18 \mathrm{~m})$

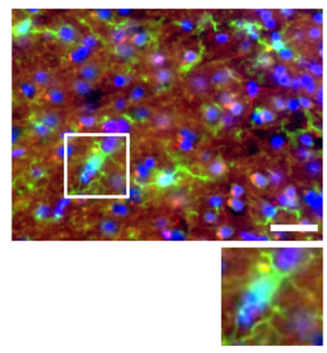

$3 \operatorname{Tg}(18 \mathrm{~m})$

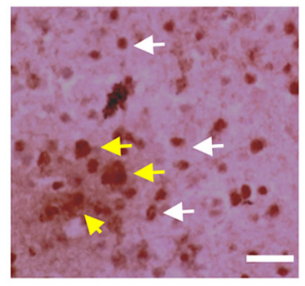

K

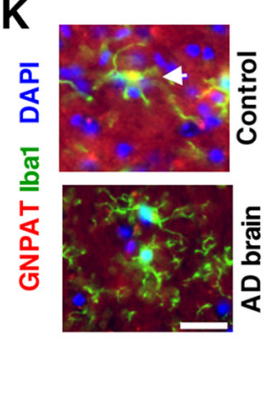

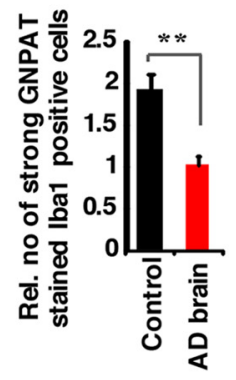

Figure 13. Increased c-MYC and reduced GNPAT expression in an AD mouse model and in human postmortem AD brain tissue. $\boldsymbol{A}$, LC-MS analysis showing a decrease in PIsEtn in 18-month-old 3Tg mice cortex compared with that of the same age control mice cortex ${ }^{*} p<0.05(n=5)$. $\boldsymbol{B}-\boldsymbol{D}$, Western blot data $(\boldsymbol{B})$ showing increased nuclear p65 and $c-$ Myc expression and reduced Gnpat expression in 18-month-old 3Tg mice brain tissues. The quantification data show an significant increase in c-Myc protein ( $\boldsymbol{C})$ and a decrease in $\mathbf{G n p a t}$ protein expression $(\boldsymbol{D})$ in 18-month-old 3Tg mice brain tissues. ${ }^{* *} p<0.01(n=5)$. $\boldsymbol{E}, \boldsymbol{F}$, Double staining of Iba-1 with c-Myc $(\boldsymbol{E})$ and $\mathrm{Gnpat}(\boldsymbol{F})$ in cortex tissue slices of 18 -month-old control and $3 \mathrm{Tg}$ mice. Scale bar, $50 \mu \mathrm{m} . \mathbf{G}, \boldsymbol{H}$, Image quantification data showing the relative number of strongly stained Iba-1 cells by c-Myc ( $\boldsymbol{G})$ and $\mathbf{G n p a t}(\boldsymbol{H})$ antibodies in the control and $3 \mathrm{Tg}$ mice brain cortex as shown in $\boldsymbol{E}$ and $\boldsymbol{F}$. These quantification data represent 5 mice in each group and 10 randomly chosen cortical areas from each mice cortex. ${ }^{*} p<0.05$ ( $n=$ 5). I, DAB staining showing strong $A \beta$ expression in 18-month-old $3 \mathrm{Tg}$ brain cortex compared with control mice of same age. Scale bar, $50 \mu \mathrm{m}$. The white arrow indicates $A \beta$ expression inside the cells and the yellow arrow indicates extracellular $A \beta$. The data represent 3 individual mice in each group. $\boldsymbol{J}, \boldsymbol{K}$, Immunohistochemistry of postmortem precentral brain tissue showing higher c-MYC expression $(\boldsymbol{J})$ and lower GNPAT expression $(\boldsymbol{K})$ among lba-1-positive cells in pathologically diagnosed AD brain compared with the non-AD brain. Statistical significance was calculated from the 10 randomly chosen observation sites (a total of about $200 \mathrm{lba}$-1-positive cells) from the same slide. The data represent the same tissue of three individual slides of the same lot. Scale bar, $50 \mu \mathrm{m} .{ }^{*} p<0.05 ;{ }^{* *} p<0.01(n=3)$.

$\mathrm{A}_{2}\left(\mathrm{PLA}_{2}\right)$ (Farooqui, 2010). Pls are found in all mammalian tissues, especially $20-30 \%$ of the glycerophospholipids in the heart and brain, in which most of the brain Pls are PlsEtn $(\mathrm{Fa}-$ rooqui and Horrocks, 2001). Pls are biosynthesized by two key enzymes in the peroxisome, GNPAT and alkylglycerone phosphate synthase (AGPS), and then transferred to the endoplasmic reticulum for the final step of the biosynthesis (Farooqui and Horrocks, 2001; Braverman and Moser, 2012). 
It is known that mutation or reduction of the Pls-synthesizing enzymes GNPAT and AGPS, as well as the defects in the peroxisome function, can give rise to the reduction of Pls content in the nervous system, making the brain susceptible to the damage seen in the diseases such as Zellweger syndrome, X-linked adrenoleukodystrophy, and rhizomelic chondrodysplasia punctate (Farooqui and Horrocks, 2001; Brites et al., 2009; Braverman and Moser, 2012; Noguchi et al., 2014). Gnpat knock-out mice exhibit dwarfism, defects in eye development, male infertility, optic nerve hypoplasia, reduction in natural killer cell activity, and demyelination of Schwann cells (Brites et al., 2011; Saab et al., 2014; da Silva et al., 2014). Some of the knock-out mice die prematurely, suggesting that the Pls contents are important for normal cellular activity. It has also been reported that AD patients show a reduction of brain and blood PlsEtn levels (Ginsberg et al., 1995; Guan et al., 1999; Han et al., 2001). Consistent with these data in humans, we found a reduction of PlsEtn in the brains of the $\mathrm{AD}$ mice model and confirmed a possible mechanistic insight behind this reduction for the first time. More surprisingly, the similar mechanism of murine cells was also observed in the human cell lines and in the human AD postmortem brain. The mechanisms of the neuroinflammation-induced reduction of Pls could be explained as follows. First, due to the Pls-specific vinyl-ether bond at the $s n-1$ position, Pls may be targeted by oxidants including reactive oxygen/ nitrogen species (Yavin and Gatt, 1972; Khaselev and Murphy, 1999; Engelmann, 2004), resulting in the reduction of Pls contents. It has been shown that Pls have antioxidant properties and oxidative stress preferentially oxidizes PlsEtn over phosphatidyl-ethanolamine (Reiss et al., 1997; Zoeller et al., 2002). Second, Pls may be degraded by Pls-selective PLA $\mathrm{A}_{2}$, which is activated by, for example, ceramide, produced under inflammatory conditions (Latorre et al., 2003; Farooqui, 2010), contributing to the loss of Pls in the brain. Finally, it has been suggested that the $\mathrm{Pls}$ biosynthesis in the $\mathrm{AD}$ patients is decreased since the high amount of $\mathrm{A} \beta$ and the $\mathrm{A} \beta$-induced ROS/ RNS may impair peroxisomal function (Grimm et al., 2011). However, the exact molecular mechanisms of the downregulation of Pls de novo synthesis have been remained elusive.

Our results demonstrate for the first time that expression of a Pls-synthesizing enzyme, Gnpat, is downregulated by inflammatory stimuli, aging, and stress in glial cells, leading to a reduction of Pls levels. Only LPS treatment reduced AGPS expression, not treatment with Poly I:C or IL-1 $\beta$. We therefore focused only the downregulation of Gnpat expression by inflammatory stimuli in our present study. The promoter studies revealed that the downregulation of Gnpat was caused by the NF- $\kappa \mathrm{B}$-mediated increase in recruitment of c-Myc onto the promoter of Gnpat gene. Therefore, the induction of c-Myc might be one of the reasons for the reduction of Pls contents in the murine brain. Interestingly, in our study, we found that the two binding sites of c-Myc on the Gnpat promoter region were equally important, but the reason for this was still elusive. It might be possible that the c-Myc recruitments could form a common complex with other transcriptional factors necessary to reduce the transcription from the Gnpat promoter. However, future experiments are necessary to address this issue. The speculation that the inflammatory signals induce c-Myc to cause pathological changes is supported by the finding that c-Myc expression is positively associated with the activation of NF- $\kappa$ B (Ji et al., 1994; La Rosa et al., 1994), which is often observed in the pathology of neuroinflammation (O'Neill and Kaltschmidt, 1997; Mattson and Camandola, 2001). We also found in the present study that the expression of c-Myc was enhanced by activation of NF- $\kappa \mathrm{B}$ in the cell lines and in the murine brain, working as a transcriptional repressor. This may be consistent with previous reports showing that $\mathrm{c}-\mathrm{Myc}$ can function as both the transcriptional activator and repressor depending on the target genes and association with the other cotranscription factors (Gartel and Shchors, 2003; Xu et al., 2009; Lüscher and Vervoorts, 2012). As was the case in murine cells, we also noticed a similar effect of NF- $\kappa \mathrm{B}$ on c-MYC and GNPAT in the human cell lines. Furthermore, we found a reduction of GNPAT and increased expression of c-MYC in the human $\mathrm{AD}$ postmortem brain. Interestingly, we found that the downregulation of Gnpat itself caused activated phenotype of microglial cells, as well as an enhancement of proinflammatory cytokine production (Fig. 10). The mechanism of the glial activation caused by decrease in Pls in the present study is not known. However, we observed that the knockdown of Gnpat induced a significant activation of NF- $\kappa \mathrm{B}$ in the glial cells, which raised the possibility that a reduction of $\mathrm{Pls}$ in the $\mathrm{AD}$ brain may not be an artifact, but rather could accelerate neuroinflammation, resulting in the prolonged/ chronic progression of $\mathrm{AD}$.

We have reported previously that application of Pls activates Akt and Erk signaling to inhibit neuronal apoptosis (Hossain et al., 2013). It has also been shown that extracellular addition of $\mathrm{Pls}$ enhances natural killer (NK) cell activity, whereas the reduction of endogenous Pls induces the death of NK cells (Ni et al., 2014). These findings support a hypothesis that the reduction of Pls may be one of the causes of neuronal damages leading to memory loss in the AD brain. It has been shown that the lipid rafts present in the cellular membrane, which are known to play an important role in signal transduction through the localization, trafficking, and regulation of G-protein coupled receptor (GPCR)-related molecules (Allen et al., 2007), are rich in Pls compared with the nonlipid rafts region (Rodemer et al., 2003). Therefore, it is possible that reduction of $\mathrm{Pls}$ content can affect signal transduction cascade. This is supported by our recent findings that Pls can activate some GPCRs, which are believed to function in the rafts (Hossain et al., 2016). However, further studies are required to demonstrate how $\mathrm{Pls}$ reduction activates $\mathrm{NF}-\kappa \mathrm{B}$ to induce neuroinflammation.

Bottelbergs et al. (2012) reported that there was not a significant increase in the expression of proinflammtory cytokines $T N F \alpha, T L R 2$, and C1q in Gnpat knock-out mice and concluded that there was no change in the inflammation status. However, they did not mention the major proinflammtory cytokines $I L-1 \beta$ and $M c p-1$ in their experiments. In addition, there was a tendency toward increased expression of TNF $\alpha$ and TLR2 in the Gnpat knock-out mice in that study. Based on our extensive experimental data, the reduction of Pls induced by knockdown of Gnpat resulted in the increased expression of $I L-1 \beta$ and $M c p-1$ in microglial cells, which was also associated with the nuclear localization of the p65 protein.

Our cumulative evidence suggests that levels of the unique glycerophospholipid, Pls, are commonly reduced by inflammatory stimuli, aging, and stress, which are pathological causes of glial activation and neuronal cell death. Further study will be needed to understand how Pls is necessary for maintaining the cellular signaling in the brain with the aim of finding possible therapeutic strategies to prevent the neuronal damage associated with various neurodegenerative diseases.

\section{References}

Abe Y, Honsho M, Nakanishi H, Taguchi R, Fujiki Y (2014) Very-longchain polyunsaturated fatty acids accumulate in phosphatidylcholine of fibroblasts from patients with Zellweger syndrome and acyl-CoA oxidase1 deficiency. Biochim Biophys Acta 1841:610-619. CrossRef Medline 
Allan SM, Tyrrell PJ, Rothwell NJ (2005) Interleukin-1 and neuronal injury. Nat Rev Immunol 5:629-640. CrossRef Medline

Allen JA, Halverson-Tamboli RA, Rasenick MM (2007) Lipid raft microdomains and neurotransmitter signalling. Nat Rev Neurosci 8:128-140. CrossRef Medline

Amor S, Puentes F, Baker D, van der Valk P (2010) Inflammation in neurodegenerative diseases. Immunology 129:154-169. CrossRef Medline

Billings LM, Oddo S, Green KN, McGaugh JL, LaFerla FM (2005) Intraneuronal Abeta causes the onset of early Alzheimer's disease-related cognitive deficits in transgenic mice. Neuron 45:675-688. CrossRef Medline

Blelloch R, Venere M, Yen J, Ramalho-Santos M (2007) Generation of induced pluripotent stem cells in the absence of drug selection. Cell Stem Cell 1:245-247. CrossRef Medline

Bligh EG, Dyer WJ (1959) A rapid method of total lipid extraction and purification. Can J Biochem Physiol 37:911-917. CrossRef Medline

Bottelbergs A, Verheijden S, Van Veldhoven PP, Just W, Devos R, Baes M (2012) Peroxisome deficiency but not the defect in ether lipid synthesis causes activation of the innate immune system and axonal loss in the central nervous system. J Neuroinflammation 9:61. CrossRef Medline

Brambrink T, Foreman R, Welstead GG, Lengner CJ, Wernig M, Suh H, Jaenisch R (2008) Sequential expression of pluripotency markers during direct reprogramming of mouse somatic cells. Cell Stem Cell 2:151-159. CrossRef Medline

Braverman NE, Moser AB (2012) Functions of plasmalogen lipids in health and disease. Biochim Biophys Acta 1822:1442-1452. CrossRef Medline

Brites P, Mooyer PA, El Mrabet L, Waterham HR, Wanders RJ (2009) Plasmalogens participate in very-long-chain fatty acid-induced pathology. Brain 132:482-492. CrossRef Medline

Brites P, Ferreira AS, da Silva TF, Sousa VF, Malheiro AR, Duran M, Waterham HR, Baes M, Wanders RJ (2011) Alkyl-glycerol rescues plasmalogen levels and pathology of ether-phospholipid deficient mice. PLoS One 6:e28539. CrossRef Medline

Chen CH, Zhou W, Liu S, Deng Y, Cai F, Tone M, Tone Y, Tong Y, Song W (2012) Increased NF-kappaB signalling up-regulates BACE1 expression and its therapeutic potential in Alzheimer's disease. Int J Neuropsychopharmacol 15:77-90. CrossRef Medline

Chinta SJ, Lieu CA, Demaria M, Laberge RM, Campisi J, Andersen JK (2013) Environmental stress, ageing and glial cell senescence: a novel mechanistic link to Parkinson's disease? J Intern Med 273:429-436. CrossRef Medline

da Silva TF, Eira J, Lopes AT, Malheiro AR, Sousa V, Luoma A, Avila RL, Wanders RJ, Just WW, Kirschner DA, Sousa MM, Brites P (2014) Peripheral nervous system plasmalogens regulate Schwann cell differentiation and myelination. J Clin Invest 124:2560-2570. CrossRef Medline

Engelmann B (2004) Plasmalogens: targets for oxidants and major lipophilic antioxidants. Biochem Soc Trans 32:147-150. CrossRef Medline

Farooqui AA (2010) Studies on plasmalogen-selective phospholipase A2 in brain. Mol Neurobiol 41:267-273. CrossRef Medline

Farooqui AA, Horrocks LA (2001) Plasmalogens: workhorse lipids of membranes in normal and injured neurons and glia. Neuroscientist 7:232-245. CrossRef Medline

Frank-Cannon TC, Alto LT, McAlpine FE, Tansey MG (2009) Does neuroinflammation fan the flame in neurodegenerative diseases? Mol Neurodegener 4:47. CrossRef Medline

Gartel AL, Shchors K (2003) Mechanisms of c-myc-mediated transcriptional repression of growth arrest genes. Exp Cell Res 283:17-21. CrossRef Medline

Ginsberg L, Rafique S, Xuereb JH, Rapoport SI, Gershfeld NL (1995) Disease and anatomic specificity of ethanolamine plasmalogen deficiency in Alzheimer's disease brain. Brain Res 698:223-226. CrossRef Medline

Goodenowe DB, Cook LL, Liu J, Lu Y, Jayasinghe DA, Ahiahonu PW, Heath D, Yamazaki Y, Flax J, Krenitsky KF, Sparks DL, Lerner A, Friedland RP, Kudo T, Kamino K, Morihara T, Takeda M, Wood PL (2007) Peripheral ethanolamine plasmalogen deficiency: a logical causative factor in Alzheimer's disease and dementia. J Lipid Res 48:2485-2498. CrossRef Medline

Grimm MO, Kuchenbecker J, Rothhaar TL, Grösgen S, Hundsdörfer B, Burg VK, Friess P, Müller U, Grimm HS, Riemenschneider M, Hartmann T (2011) Plasmalogen synthesis is regulated via alkyl-dihydroxyacetonephosphate-synthase by amyloid precursor protein processing and is affected in Alzheimer's disease. J Neurochem 116:916-925. CrossRef Medline

Guan Z, Wang Y, Cairns NJ, Lantos PL, Dallner G, Sindelar PJ (1999) Decrease and structural modifications of phosphatidylethanolamine plas- malogen in the brain with Alzheimer disease. J Neuropathol Exp Neurol 58:740-747. CrossRef Medline

Han X, Holtzman DM, McKeel DW Jr (2001) Plasmalogen deficiency in early Alzheimer's disease subjects and in animal models: molecular characterization using electrospray ionization mass spectrometry. J Neurochem 77:1168-1180. CrossRef Medline

Hartmann T, Kuchenbecker J, Grimm MO (2007) Alzheimer's disease: the lipid connection. J Neurochem 103:159-170. CrossRef Medline

He TC, Chan TA, Vogelstein B, Kinzler KW (1999) PPARdelta is an APCregulated target of nonsteroidal anti-inflammatory drugs. Cell 99:335345. CrossRef Medline

Hossain MS, Ozaki T, Wang H, Nakagawa A, Takenobu H, Ohira M, Kamijo T, Nakagawara A (2008) N-MYC promotes cell proliferation through a direct transactivation of neuronal leucine-rich repeat protein-1 (NLRR1) gene in neuroblastoma. Oncogene 27:6075-6082. CrossRef Medline

Hossain MS, Ifuku M, Take S, Kawamura J, Miake K, Katafuchi T (2013) Plasmalogens rescue neuronal cell death through an activation of AKT and ERK survival signaling. PLoS One 8:e83508. CrossRef Medline

Hossain MS, Mineno K, Katafuchi T (2016) Neuronal orphan G-protein coupled receptor proteins mediate plasmalogens-induced activation of ERK and Akt signaling. PLoS One 11:e0150846. CrossRef Medline

Hossain S, Takatori A, Nakamura Y, Suenaga Y, Kamijo T, Nakagawara A (2012) NLRR1 enhances EGF-mediated MYCN induction in neuroblastoma and accelerates tumor growth in vivo. Cancer Res 72:4587-4596. CrossRef Medline

Ifuku M, Katafuchi T, Mawatari S, Noda M, Miake K, Sugiyama M, Fujino T (2012) Anti-inflammatory/anti-amyloidogenic effects of plasmalogens in lipopolysaccharide-induced neuroinflammation in adult mice. J Neuroinflammation 9:197. Medline

Ifuku M, Hossain SM, Noda M, Katafuchi T (2014) Induction of interleukin-1beta by activated microglia is a prerequisite for immunologically induced fatigue. Eur J Neurosci 40:3253-3263. CrossRef Medline

Ji L, Arcinas M, Boxer LM (1994) NF-kappa B sites function as positive regulators of expression of the translocated c-myc allele in Burkitt's lymphoma. Mol Cell Biol 14:7967-7974. CrossRef Medline

Kettenmann H, Hanisch UK, Noda M, Verkhratsky A (2011) Physiology of microglia. Physiol Rev 91:461-553. CrossRef Medline

Khaselev N, Murphy RC (1999) Susceptibility of plasmenyl glycerophosphoethanolamine lipids containing arachidonate to oxidative degradation. Free Radic Biol Med 26:275-284. CrossRef Medline

Kozlowski C, Weimer RM (2012) An automated method to quantify microglia morphology and application to monitor activation state longitudinally in vivo. PLoS One 7:e31814. CrossRef Medline

La Rosa FA, Pierce JW, Sonenshein GE (1994) Differential regulation of the c-myc oncogene promoter by the NF-kappa B rel family of transcription factors. Mol Cell Biol 14:1039-1044. CrossRef Medline

Latorre E, Collado MP, Fernández I, Aragonés MD, Catalán RE (2003) Signaling events mediating activation of brain ethanolamine plasmalogen hydrolysis by ceramide. Eur J Biochem 270:36-46. CrossRef Medline

Lüscher B, Vervoorts J (2012) Regulation of gene transcription by the oncoprotein MYC. Gene 494:145-160. CrossRef Medline

Maeba R, Araki A, Ishii K, Ogawa K, Tamura Y, Yasunaga M, Minami U, Komori A, Okazaki T, Nishimukai M, Hara H, Fujiwara Y (2016) Serum ethanolamine plasmalogens improve detection of cognitive impairment among elderly with high excretion levels of urinary myo-inositol: a crosssectional study. Clin Chim Acta 453:134-140. CrossRef Medline

Mattson MP, Camandola S (2001) NF- $\kappa$ B in neuronal plasticity and neurodegenerative disorders. J Clin Invest 107:247-254. CrossRef Medline

Nadjar A, Combe C, Layé S, Tridon V, Dantzer R, Amédée T, Parnet P (2003) Nuclear factor kappaB nuclear translocation as a crucial marker of brain response to interleukin-1. A study in rat and interleukin-1 type I deficient mouse. J Neurochem 87:1024-1036. Medline

Ni G, Li Z, Liang K, Wu T, De Libero G, Xia C (2014) Synthesis and evaluation of immunostimulant plasmalogen lysophosphatidylethanolamine and analogues for natural killer T cells. Bioorg Med Chem 22:2966-2973. CrossRef Medline

Noguchi M, Honsho M, Abe Y, Toyama R, Niwa H, Sato Y, Ghaedi K, Rahmanifar A, Shafeghati Y, FujikiY (2014) Mild reduction of plasmalogens causes rhizomelic chondrodysplasia punctata: functional characterization of a novel mutation. J Hum Genet 59:387-392. CrossRef Medline

Oddo S, Caccamo A, Shepherd JD, Murphy MP, Golde TE, Kayed R, Metherate R, Mattson MP, Akbari Y, LaFerla FM (2003) Triple-transgenic 
model of Alzheimer's disease with plaques and tangles: intracellular Abeta and synaptic dysfunction. Neuron 39:409-421. CrossRef Medline

O’Neill LA, Kaltschmidt C (1997) NF- $\kappa$ B: a crucial transcription factor for glial and neuronal cell function. Trends Neurosci 20:252-258. CrossRef Medline

Reiss D, Beyer K, Engelmann B (1997) Delayed oxidative degradation of polyunsaturated diacyl phospholipids in the presence of plasmalogen phospholipids in vitro. Biochem J 323:807-814. CrossRef Medline

Rodemer C, Thai TP, Brugger B, Kaercher T, Werner H, Nave KA, Wieland F, Gorgas K, Just WW (2003) Inactivation of ether lipid biosynthesis causes male infertility, defects in eye development and optic nerve hypoplasia in mice. Hum Mol Genet 12:1881-1895. CrossRef Medline

Rubinson DA, Dillon CP, Kwiatkowski AV, Sievers C, Yang L, Kopinja J, Rooney DL, Zhang M, Ihrig MM, McManus MT, Gertler FB, Scott ML, Van Parijs L (2003) A lentivirus-based system to functionally silence genes in primary mammalian cells, stem cells and transgenic mice by RNA interference. Nat Genet 33:401-406. CrossRef Medline

Saab S, Buteau B, Leclère L, Bron AM, Creuzot-Garcher CP, Bretillon L, Acar $\mathrm{N}$ (2014) Involvement of plasmalogens in post-natal retinal vascular development. PLoS One 9:e101076. CrossRef Medline

Sanjabi S, Williams KJ, Saccani S, Zhou L, Hoffmann A, Ghosh G, Gerondakis S, Natoli G, Smale ST (2005) A c-Rel subdomain responsible for en- hanced DNA-binding affinity and selective gene activation. Genes Dev 19:2138-2151. CrossRef Medline

Srinivasan D, Yen JH, Joseph DJ, Friedman W (2004) Cell type-specific interleukin-1beta signaling in the CNS. J Neurosci 24:6482-6488. CrossRef Medline

Xu B, Liu P, Li J, Lu H (2009) All-trans retinoic acid induces Thrombospondin-1 expression in acute promyelocytic leukemia cells though down-regulation of its transcription repressor, c-MYC oncoprotein. Biochem Biophys Res Commun 382:790-794. CrossRef Medline

Yavin E, Gatt S (1972) Oxygen-dependent cleavage of the vinyl-ether linkage of plasmalogens. 2. Identification of the low-molecular-weight active component and the reaction mechanism. Eur J Biochem 25:437-446. CrossRef Medline

Zhou J, Struthers AD, Lyles GA (1999) Differential effects of some cell signalling inhibitors upon nitric oxide synthase expression and nuclear factor-kappaB activation induced by lipopolysaccharide in rat aortic smooth muscle cells. Pharmacol Res 39:363-373. CrossRef Medline

Zoeller RA, Grazia TJ, LaCamera P, Park J, Gaposchkin DP, Farber HW (2002) Increasing plasmalogen levels protects human endothelial cells during hypoxia. Am J Physiol Heart Circ Physiol 283:H671-679. CrossRef Medline 